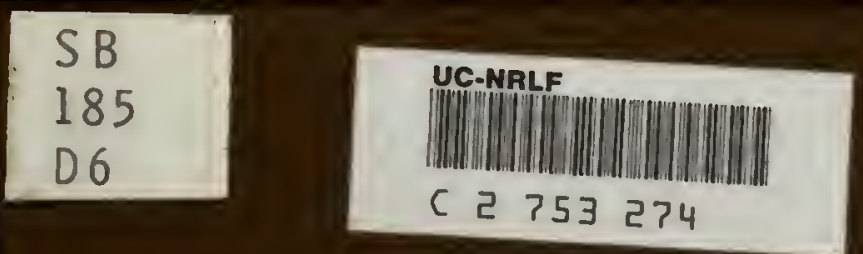


LIBRARY

UNIVERSITY OF CALIFORNIA

DAV1S 
I

(1)

$-$ 


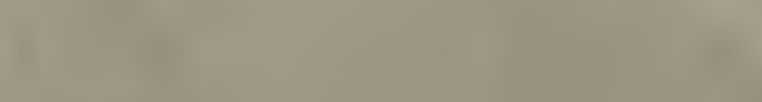

$+2$

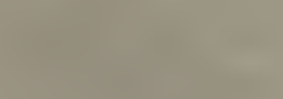

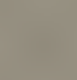

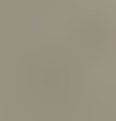


Digitized by the Internet Archive in 2007 with funding from Microsoft Corporation 
FODDER CROPS OF THE PUNJAB. 
INDEX.

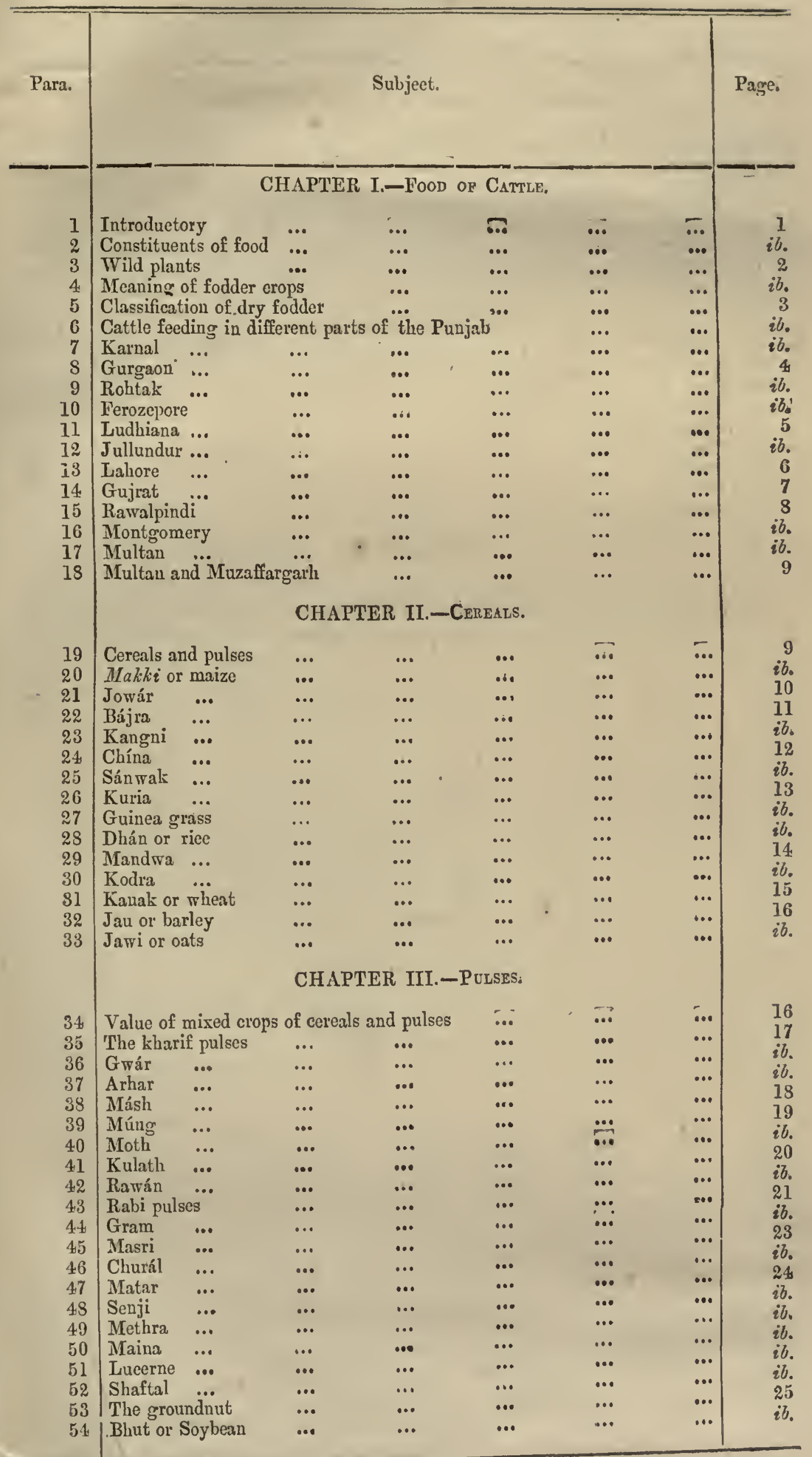




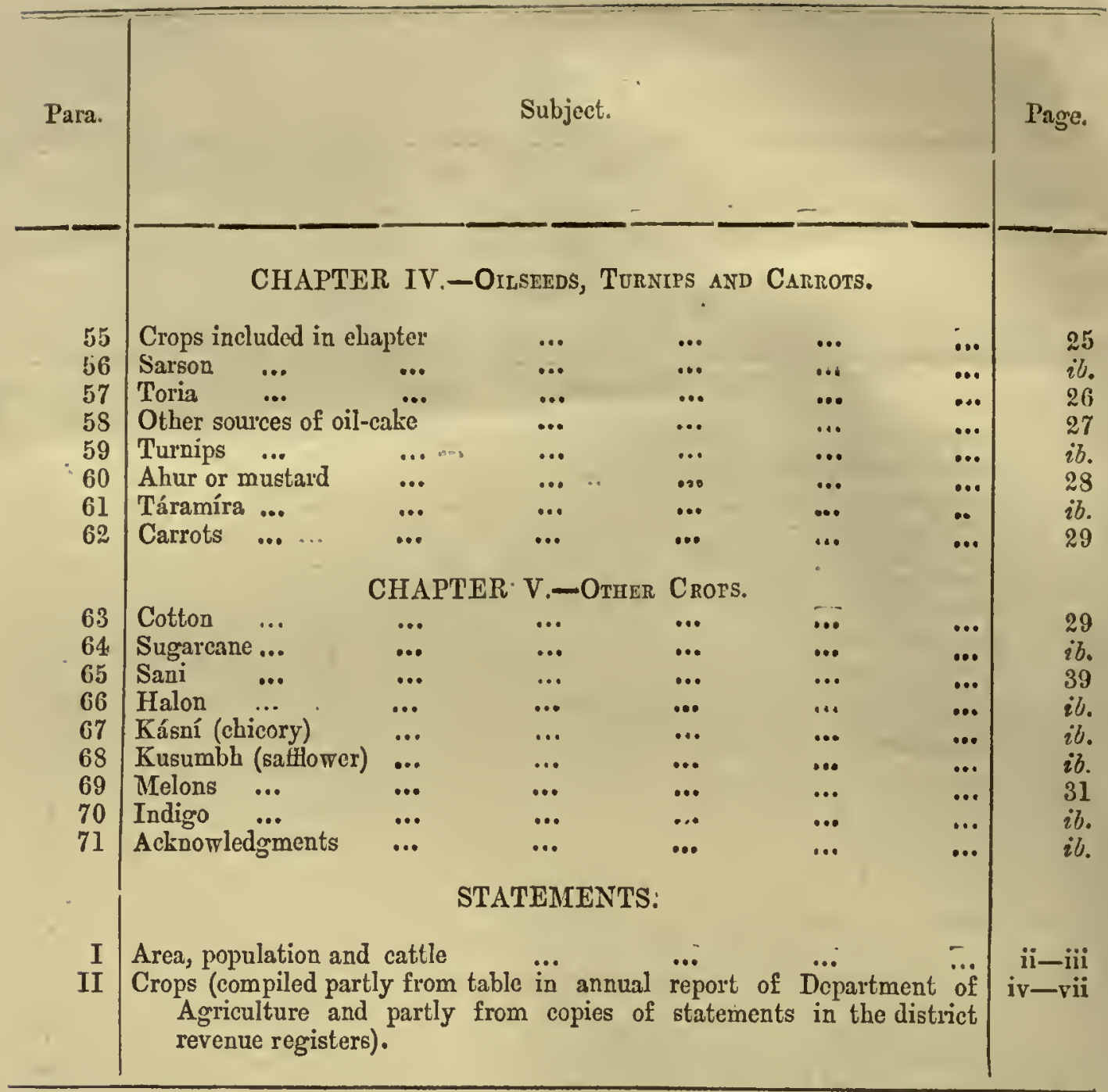




\section{THE FODDER CROPS OF THE PUNJAB.}

\section{CHAPTER I.-FoOd OF CATTLE.}

1. From the nature of the country, agrieulture must always be the Introductory.

chicf oecupation of the pesple of the Punjab. According to the recent census the population of the 29 districts was nearly 20 inillions. In round figures the cultivated area in 1906-07 amounted to 28 million acres, and pasture lands including Government forests to 18 millions. The well-irrigated area was 5 inillion acres, dependent on quarter of a million masonry and from 30 to 40,000 kachcha wells. The area protected by canals was $6 \frac{3}{4}$ millions of acres - an area to which large additions will be made. An aren of 275,000 acres was recorded as $a b i$, and the unirrigated area exceeded 16 million acres. Aceording to the cattle census of 1909 there were in that year 2,169,000 ploughs and 285,000 carts. The horned cattle available for draft were-

\section{4,247,000 bullocks, and}

\section{5,000 male buffaloes.}

The former figures include bulls, and if we exclude animals used for breeding, we may say there are $4 \frac{1}{2}$ millions of animals available to plough the land, work the wells, thresh the corn, draw the carts, and work sugar, oil and flour mills. Camels are used for ploughing to some extent in Hissar and Ferozepore, and in Rawalpindi a doulicy or a cow is sometimes seen yoked with a bullock. The milch kine consisted of 3,384,000 cows and 2,241,000 buffaloes, and the young stock, male and female, was returned as amounting to $3,820,000$. Femalo buffaloes are far more valuable than cows, and are steadily growing in favour. They are also coarser feeders. The only districts in which little attention is still paid to them are a group of four in the northwest of the province, Jhelum, Rawalpindi, Attock and Mianwali, and two of the sonth-westeru distriets, Mizaffargarh and Dera Ghazi Khan (see for details statement I). Roughly there are $14 \frac{1}{2}$ millious of horned cattle dependent for natural grazing on 18 million aeres of waste, much of it of poor quality, which they have to share with 4 million sheep and $5 \frac{1}{3}$ / million goats. The large areas of waste are found in a few districts, mostly in the west of the provinee and in the hills. In the four plain districts of the Jullundur division the waste is only equal to 12 per cent. of the cultivation, in the Lahore division excluding Gujranwala it is 20 , and in the Delhi division excluding Simla 21 per eent. The products of the waste are supplemented by those of the fallow and by the grasses and other plants weeded out of the cropped fields. It is obvious that in the Punjab a very large acreage must be devoted to raising food for cattle, and that fodder crops must be of vast importance. Broadly speaking, the province is now secure from widesprearl food famines, but fodder famines can still inflict enormous losses on the people.

2. The following extracts from Moreland's Agricnlture of the United

"This food is produced in the parent plant from the materials that it has collected from the soil or the air and passes into the developing seed; large numbers of different substances are stored in this way by different plants, but they can be grouped in two main classes according as they do or do not contain combined nitrogen . . . . The non-nitrogenous matter is usually cither starch or oil, while the nitrogenous matter is in various forms which are known colleetively as albuminoids or proteids . . . . . . . Animals are made up of preeisely the same elementary substances as plants, though they require to consume these substances in different forms, and convert them into such things as skin, bones and muscles, not leaves, flowers, or seed. We have seen that the most important product of plants from. the nutritive point of view are (1) starch and the various sugars, and $(2)$ the proteids; when speaking of animals it is more convenient to call those respectively work food and flesh food. 
The first class supply energy which enahles an animal to go on working, but the second class (which it will be remembered contain nitrogen) are essential to replace the rrear and tear of substance that is constantly going on in an animal body; in order to feed an animal so as to get the best work out of it, it is neeessary not only to see that the weight of food given is suffieient, but also that it contains a due proportion of flesh food. Now we have seen that most of the flesh food produced by plants is stored in the seeds, and very little of it in the leaves and stems*: it follows that when eattle are doing hard work they ought to receive a fair amount of seed or grain as well as fodder, and even when they are idle some grain should be given to keep them in really good health."

For further information about food and the nutritive value of different grains, Chureh's "Food Grains of India " may be consulted. It is worth while to note that a standard diet for human beings should contain albuminoids and starch in about the proportion of $1-5$. This is very much the proportion in which they exist in wheat, but in the millets and maize the proportion is about $1-8$, in rice about $1-11$, and in mandwa $1-13$. In pulses the proportion of albuminoids to starch is much higher than $1-5$; hence the utility of such mixtures as riee and dál or bájra and moth khichri (porridge). The analyses of the chemical eontents of the grain of different crops given in this note are taken from Professor Chureh's bock. In paragraph 239 of his work on the "Improvement of Indian Agriculture" the late Dr. Vocleker remarked in 1893 that little was known as to the relative nutritive values of different fodders in India, and apparently this has so far not been remedied. No doubt the straw of the pulses generally contains more albuminoids than that of the cereals, and it is on this account that they are weight for weight more valuable as fodder.

3. We are not here concerned with the wild plants which furnish food wild plants. for cattle. The list of trees, shrubs and herbs on which they feed is a very long one. A large part of it is occupied with the names of grasses, and of leguminous trees, such as various speeies of acacia and the dhak (Butea frondosa) and herbs, sueh as maina or maini (Medicago denticulata', a ncar relation of lucerne. For information the following may be referred to:-

(a) Duthie's "Fodder Grasses of Northern India."

(b) Coldstream's "Grasses of the Southern Punjab."

(c) Duthie's four lists on pages $407-437$ of volume III of the Dictionary of Economic Products.

It is probable that considerable additions could be made to the lists of flowering plants other than grasses.

The two best fodder grasses in the plains are anjan or dhaman (Pennisetum cenchroides), and dúb, dutira, or khabbal (Cynodon dactylon), and the most useful shrub is the jharrberi or malla (Zizyphus nummularia), the leaves of which, pála, are a very valuable food for milch kine.

4. The food of cattle, so far as it is derived from erops, may be classified Meaning of "fodier crops." as consisting of -

(a) straw-Vern. "chára" or " nira";

(b) the roots and tops of ecrtain cruciferous plants, such as turnips and earrots ;

(c) gram;

(d) oil-cake-"khal" or "khali";

(c) eotton seeds-" binola" or "varenva".

It is only with the first two that a note on fodder crops is directly concerned "Fodder" according to a dietionary definition is "food for cattle, horses, and sheep, as hay, straw, and other kinds of vegetables." This is somewhat vague. A good working definition woisld be "the food derived by live-stock from erops exclusire of the ripe grain." Thus the ripe grain of wheat, or másh or jowar

* See in this connection chemical analysis of grain and straw of jowar in parngraph 21. 
is not fodder, but the leaves and stalks, and in the case of másh the broken pods left after threshing are fodder. Cotton-seed is not fodder, and aceording to our definition oil-eake is also exeluded, because it is the refuse left after grain has been expressed from the ripe seeds of certain crops. The number of purely fodder crops in the Punjab is really very small consisting of some of tho pulses and one or two other piants. But any account of fodder crops would be incomplete which did not notice the use as fodder of the straw of crops whose grain is mainly used as human food. And it will be convenient also to mention the crops from which oil-cake is derived, especially as tho chicf of them also supply green food and roots for cattle.

Classification of dry fodder.

5. Dry fodder may he broadly classified as-

(a) Bhisa, bhis, bho, or thon. Broken straw of those cercals and pulses of which the straw is threshed with the grain. Of this there are two main divisions -

(1) turi or sufed bhusa, which is the straw of wheat and barley, and

(2) missa bhisa, which is the broken leaves, straw, and pods of moth, müng, másh, masar, and gram;

(b) tánda or stalks of maize, bájra and jowár, which are not threshed with the grain. These are usually fed to cattle after bein $g$ chopped up into small picees :

(c) parál or paráli, which is the straw of rice.

6. Speaking generally, the people feed cows and still more buffaloes Cattle feeding in different parts of the Prnjab. when in milk better than they do their plough and well bullocks. The zamindars of the cis-Suttlej districts are better stock-keopers than those of the Punjab proper. The care which a peasant in Rohtak bestows on his female buffalo is remarkable, and even in seasons of severe drought one sees them coming out of the village sleek and well faroured. The feeding of cattle on turnip roots is far more common in the western districts than elsewhere, and it is in the same distriets that peas (churál and matar), and, so far as the plains are concerned, the inferior cercals, known as chína and swánk, are most in use. Some extracts and notes are appended regarding cattle-feeding in some-

(1) cis-Sutlej,

(2) trans-Sutlej,

districts.

\section{A.-Cis-Sutlej districts.}

7. "The fodder of the autumn crops consists of the stalks (tanda) of the Karnal (Gazetteer, edition of 1890, paragraph 222). great millets and of maize, which are carcfully stacked on end in a stack called chhor; of rice straw, which is merely piled up in a heap (kunjra); and of the bhis or broken straw of the pulses. The spring crops give bhís only, also called turi if of wheat or barley.

Stems of millet and maize are chopped up into small pieees (sani or kuti) before being given to the cattle. An ox doing ordinary work will eat 20 sers of grass and a ser of grain daily; if working at the sugar-mill or well-bucket, nearly twice that......... Of course the fodder varies according to the season. 'The mass of it consists of grass and straw of cereals; a little pulse straw is always added, and green food when obtainable. In the cold weather methi and rape and carrots, and at all times the weedings, are given to the cattle. Besides this, some cotton seed or oil-cake, or eithcr gucio' moth, or gram, is daily given. The best fodder of all is the straw of the small pulses, and is called missa; after that that of wheat and barley called turi; after that the jowár stems or chari. Bájza stems are seldom given alone. They are chopped up and mixed with onc-third of múng fodder, or, failing that, with some oil- 
cake or peameal of gram. In famines the cattle will eat almost anything. 'The sacred pipals are stripped, and evon the thorny hins (Capparis sepiaria) is cut up and given to the starving beasts. Where sugarcane is grown it is cut down to keep the bullocks alive."

8. "The grazing on such waste as there is is supplemented by the Gargaon (Gazettcer, page 1(9). grazing on cultivated lands lying fallow, but on the whole grazing is inadequate. In consequence the cattle hare to be largely stall-fed, and considerable areas of crops are grown exclusivcly for fodder. Chari, guár, and hásni are exclusirely fodder crops, while of other erops most of the peas, carrots, and turnips, about one-quarter of the sarson and autumn pulses, and small quantities of barley and gram are given to the cattle. To these must be added the stalls of jowár and bájra, the straw of the autumn pulses and rabi cereals, cotton seed, oil-cake, and pála. In good year's all the above sourees supply the zamin. dar's with an abundance of good fodder, but, if the rains fail, a dearth of fodder and terrible loss of cattle result. Then fodder is searce the cattle are fed on branches of trees, roots of puila, etc."

9. "The cattle of the district are in some respects illocared for. They Rohtak (Gazettecr, paragraph 129). are left to stand in filthy enclosures (neora or ngár), ankie-deep in halfliquid manure. They are ehiefly stall-fed, chopped jowar stalks (sani) being the principal fodder, while in scason the top leaves of the cane will be mixed, or some green sarson toppings. Working stock will get half a ser to a ser of gram a clay, and a little gur, and milcl cattle also eat cotton seed (binola) and oil-cake (khal), while the straw of gwár (phaliar) and of ming and rird (patti) and of gram (khar) are higbly valued for eattle, and the wild jhárberi is giren for its milk-producing qualities. Best fed and best tended is tho butfalo, and every day the village urchins may be seen carefully wasling them in the tanks. In the morning the eattle are turned out for exercise, and to pick up what they can in the raste ground of the village, but there are fow patehes of jungle which produce more than indiflerent grass. When the erops are off the fields the stubble is grazed by all the cattle of the village.

The jowár and bajra stalks of a good ycar are usually counted to be sufficient for the current and one following year, though in a rain-land village, where the arca under these crops is larger, it will last rather longer. Bajja fodder is not used so long as the jowár lasts."

10. (Based on a note by Rai Bahadur Tilok Chand, Sub-Divisional Ferozepore.

Officer of Farillia.) The cattle of the Uplands or Rohi are of the Hissar and Nagore breed, and much finer than those of the Bet. A zamindar with a pair of bullocks would usually also lieep a cow, a female buffalo, and some calres. Their food would be as follows :-

\begin{tabular}{|c|c|c|c|}
\hline No. & Months. & Grain. & Straw. \\
\hline 1 & Daisakh (16th April-15th May) & No grain, except to milch cattle, which get & Graze in subble of \\
\hline 2 & Jeth (16th Nay-15th June) & $\begin{array}{l}\text { Khali and grain to working and milch } \\
\text { cattle. }\end{array}$ & $\begin{array}{l}\text { Whert and gram. } \\
\text { Bhisa. }\end{array}$ \\
\hline 3 & Har to Asoj (16th Jnne-15th October) & $\begin{array}{l}\text { Two sers of gram or groára daily to each } \\
\text { working animal or to milch kine when } \\
\text { pregnent or gwing milk. }\end{array}$ & $\begin{array}{l}\text { Chari, if arailable; } \\
\text { otherwise bhúsa. }\end{array}$ \\
\hline 4 & $\begin{array}{l}\text { Katale and Magghar (16th October }-15 \text { th } \\
\text { Necember). }\end{array}$ & $\begin{array}{l}\text { No grain, as gwára (sce next column) is } \\
\text { considered a rich food. }\end{array}$ & Gwára. \\
\hline 5 & $\begin{array}{l}\text { Poh and Niagh (16th December-15th } \\
\text { liebruary). }\end{array}$ & As No, 1 & Bhúsa. \\
\hline 6 & $\begin{array}{l}\text { Phagan and Cbait (16th February }-15 \text { th } \\
\text { April). }\end{array}$ & No grain & $\begin{array}{l}\text { Green wheat (khawia ) } \\
\text { or green gram. }\end{array}$ \\
\hline
\end{tabular}

Half-ground gram (átc) is generally used and it is often mixed with bhísa. The grain of guára is boiled before it is given to cattle. While cows and 
buffaloes, are in milk they get khali or oil-cake and binola or cotton seed. A cow gets half a scr of lihali and one ser of binola, and a female buffalo twice these quantities. Khali is also sometimes given to working bullocks in Baisakh and Jeth when they are employed in threshing grain. It is supposed to be cooling. The oil-cake used in Ferozepore is ti] in winter and sarson or táramíra in summer. The milch kine are looked after very carefully in winter, and get gram or gwára as well as oil-cake and cotton seed. In the Bet the zamindars cannot afford to give their well bullocks much grain. But if they are in hard work and are getting weak, a ser of gram or wheat is given daily. This is generally done in the ploughing season for rabi crops ( $A$ soj and Katak). Wilch kine in the Bet do not get oil-cake or cotton seed, but they get a ser of grain daily for two or three months in the cold weather. The zamindar's, when they run short of bhúsa, as often happens, use sarr grass (Saccharmm ciliare), cut into small pieces mixed with green chari, sarson, táramirca, or green wheat (cf. paragraph 19 of Steedman's Settlement Report of Jhang). The Bet zamindars grow turnips as fodder, usually three ghumaos on each well, and feed the cattle on them for a month or a month and-a-half in Poh and Nagh.

In the south of the Ferozepore district the camel is used for ploughing and riding as well as for carrying burdens. They get gram and gwár grain and the straw of gwair, moth and gram.

11. The feeding of bullocks is described in paragraph 131 of Mr. (now Ludhians. Sir Thomas, Gordon Walker's Settlement Report :-

"In the months of Baisakh, Jeth, Har (April-June) the cattle are fed on dry straw and grain, the new straw of the rabi coming in by the first of these montls. This is the worst time fol them, and the working cattle could not get on without the ser or two sers of grain that they get daily. In Sawan and Bhadon there is good grass in the waste if any is loft, and in the fields intended for the next rabi, where it is allowed to grow till the time of tles Sawan ploughing. The cattle are grazed on this, and it is also grubhed up and given to them in the stall, the grain being stopped. Cutting grass is the work in Jat villages of the women who are out all day in the fields, collecting bundles. The cattle have very light work in these two months, because the wells are not working; and between this and the new grass they put on condition. In Asoj and half of Katak (September to October) green fodder, either "chari" alone or mixed with moth, \&c., is given; and this is perhaps the best time of the whole year for the cattle. At the end of Katak the "chari," \&cc., is cut and stored; and during Magghar, Poh, Magh, and Phagun the dry stalls of chari, maize, \&e., are given, and, if necessary, straw. The straw is either white ("sufed bhrisa"), that of barley and wheat, or " "nissa," i.e., of moth, másh, \&e., coloured straw. The latter, especially the moth straw, is said to be very strengthening. In the month of Chait (March) patehes of green fodder are grown at the wells, either " metha," "senji," \&c., or earrots; and green wheat or barley is also given, but not eommonly in an ordinary year."

The grain that is given is gram coarsely ground sprinkled on the turi. They are also given a little oil-cake.

Mr. Dunnett has supplied me with the following account of the fecling of milch kine in Ludhiana :-

"Milch eattle in this district are generously fed. The basis of their food is of conrese turi and the straw of pulses, and they get some of the maize stalks and the metha. But they are not usually allowed to have any of the gwára. That.fodder is filling and improves the appearance, but is said to be in reality werkening and prejudieial to a good milk yield. T'uri reinforced with grain, kihali, and binola are given. The grain is always gram. Jowár grain canses swelling in the mouth and throat (I am merely repeating what is said), and gives little milk. The grain of pulses is hot, and dries up the milk. Frequently all three (gram, binola and $k$ hali) are mixed with the turi, but more usually khali is moistened and mixed with turi, and mram ata is then sprinkled over it. The ealeulation is that gram is feeding and strengthening, while klhali and linola improve the quantity of milk and increase the percentage of butter. A little gur is sometimes given. Only the eastern half of the district grows cotton to any extent; all the cotton is sold in Khanna, and the binola has to be brought back from the factories. The people of the western lialf of the district get linola from Khanna and Ludhiaua, and consequently do not feed it freely to the cattle."

\section{B.-Trans-Sutlej districts.}

12. "During Baisakh, Jeth and Har (middle of April to middle of July) the broken straw of wheat Jullundar (Gazetteer, pages 196-97). is the principal food (of the cattle). Broken barley, massar, and gram straw may also be gịven, but barley 
and messer are little grown. Senji is oecasionally stored, and, when this is the ease, it is given to the cattle during these months. During the next two months Saran-Bhadon) there is plenty of grass in uncultivated plots and in fields lying fallow. This is grazed and also dug up and brought lome for the cattle. Next month (Asoj, 16th September-15th October) green chari alone, or mixed with moth or ming, comes in and supplies food for nearly two montlis. About the end of October the ehari left is cut down and stacked, and for the next four montlis it forms the prinejpal food, being supplemented by maize stalks and, as soon as the cane crushing begins, about the end of Norember, by the arrow of the eanes, which is fed mixed with broken stran. During February and . Tarch green fodder crops as methi, senji, and húlon are cut down as needed, and giren to cattle in the same way as cane tops were previously. If the rains hold off, the people are put to great straits to feed their cattle ; sugarcane is cut for this purpose, but it is a poor fodder and does not suit for any length of time; the leares of the dhak tree (Butea frondosa) are extensively used on such occasions............ Then corrs and buffaloes are about to calre and when they are in milk they often get grain, eotton seed, and oil-cake, but the amount depends on the owner's means, and nothing can be said about the quantity."

13. The following dictary for the canal-irrigated tract in the Lahore Caliore. Manjha has been supplied by Rai Bahadur Hotu Singh :-

\begin{tabular}{|c|c|c|c|c|c|c|c|}
\hline \multicolumn{2}{|c|}{ Montis. } & & \multicolumn{4}{|c|}{ Graiu. } & Straw. \\
\hline Outuliz... & $\cdots$ & $\cdots$ & $\begin{array}{l}\text { Bulleck } \\
\text { Cor } \\
\text { Buffalo }\end{array}$ & $\ldots$ & $\begin{array}{l}\left\{\begin{array}{l}1 \text { ser gram } \\
1 \text { ser binola }\end{array}\right. \\
\left\{\begin{array}{l}1 \text { sers binola } \\
1 \text { serkhali }\end{array}\right.\end{array}$ & \begin{tabular}{l|l}
$\ldots$ & \\
$\ldots$ \\
$\ldots$ \\
$\ldots$
\end{tabular} & 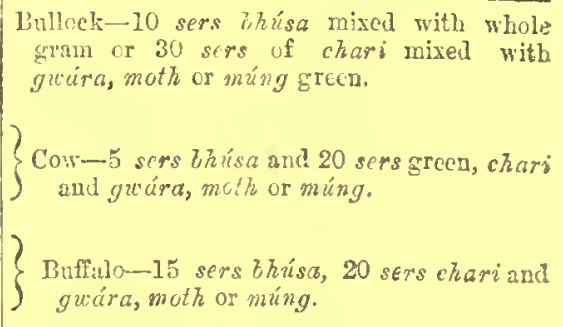 \\
\hline Nevember & $\cdots$ & $\cdots$ & Cow & $\begin{array}{l}\cdots \\
\cdots \\
\cdots\{\end{array}$ & $\begin{array}{l}\text { None... } \\
\left\{\begin{array}{l}1 \text { ser binola } \\
1 \text { ser grain }\end{array}\right. \\
\left\{\begin{array}{l}4 \text { sers binola } \\
1 \text { ser khali }\end{array}\right.\end{array}$ & $\begin{array}{c}\ldots \\
\ldots \\
\ldots \\
\ldots\end{array}$ & 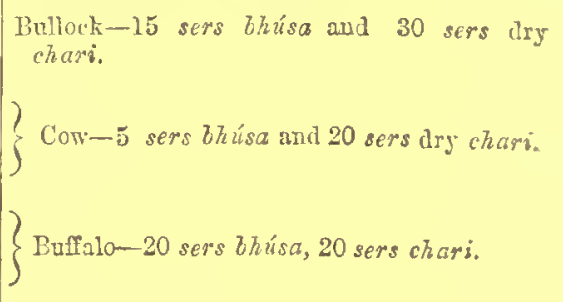 \\
\hline December & $\ldots$ & ... & $\begin{array}{l}\text { Is in No } \\
\text { grain in }\end{array}$ & $\begin{array}{l}\text { veml } \\
\text { first }\end{array}$ & $\begin{array}{l}\text { 1)er, but bullo } \\
15 \text { days. }\end{array}$ & & As in Norember. \\
\hline Jazuny... & $\cdots$ & $\cdots$ & $\begin{array}{l}\text { Cow } \\
\text { Buffaio }\end{array}$ & $\begin{array}{l}\cdots \\
\cdots \\
\cdots\end{array}$ & $\begin{array}{l}\text { None ... } \\
\left\{\begin{array}{l}1 \text { ser binola } \\
1 \text { ser grain }\end{array}\right. \\
\left\{\begin{array}{l}4 \text { sers binola } \\
1 \text { ser khati }\end{array}\right.\end{array}$ & \begin{tabular}{l|l}
$\ldots$ & \\
$\ldots$ & \\
$\ldots$ & \\
$\ldots$ &
\end{tabular} & 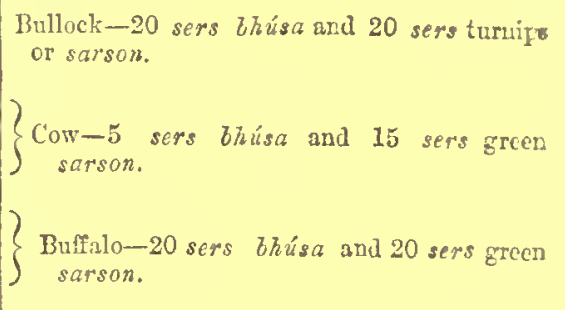 \\
\hline Tetruas & $\cdots$ & ... & $\begin{array}{l}\text { Bulleck } \\
\text { Cow } \\
\text { Buffalo as }\end{array}$ & $\begin{array}{l}\cdots \\
\cdots\end{array}$ & $\begin{array}{l}\text { None ... } \\
\text { 1 ser binola } \\
\text { January... }\end{array}$ & $\ldots$ & $\begin{array}{l}\text { Bullock-15 sers } t h u \text { sa and } 60 \text { sers senji or } \\
\text { green barley. } \\
\text { Cow-5 sers bhusa and } 25 \text { sers senji or } \\
\text { barley. } \\
\text { Bnffalo-20 sers bhusa end } 20 \text { sers senji or } \\
\text { barley. }\end{array}$ \\
\hline March ... & $\ldots$ & $\cdots$ & $\begin{array}{l}\text { Bulleck } \\
\text { Cow } \\
\text { Buffalo }\end{array}$ & $\begin{array}{l}\ldots \\
\ldots \\
\cdots\end{array}$ & $\begin{array}{l}\text { None ... } \\
\text { None ... } \\
\left\{\begin{array}{l}1 \text { ser binola } \\
2 \text { sers grain }\end{array}\right.\end{array}$ & \begin{tabular}{l|}
$\ldots$ \\
$\cdots$ \\
$\cdots$ \\
$\cdots$
\end{tabular} & 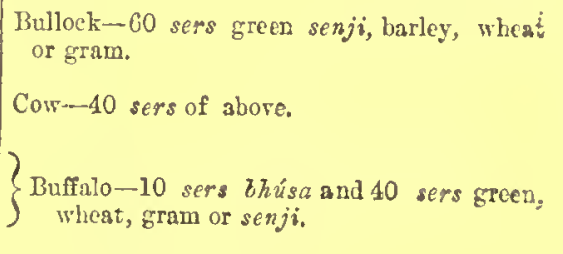 \\
\hline
\end{tabular}




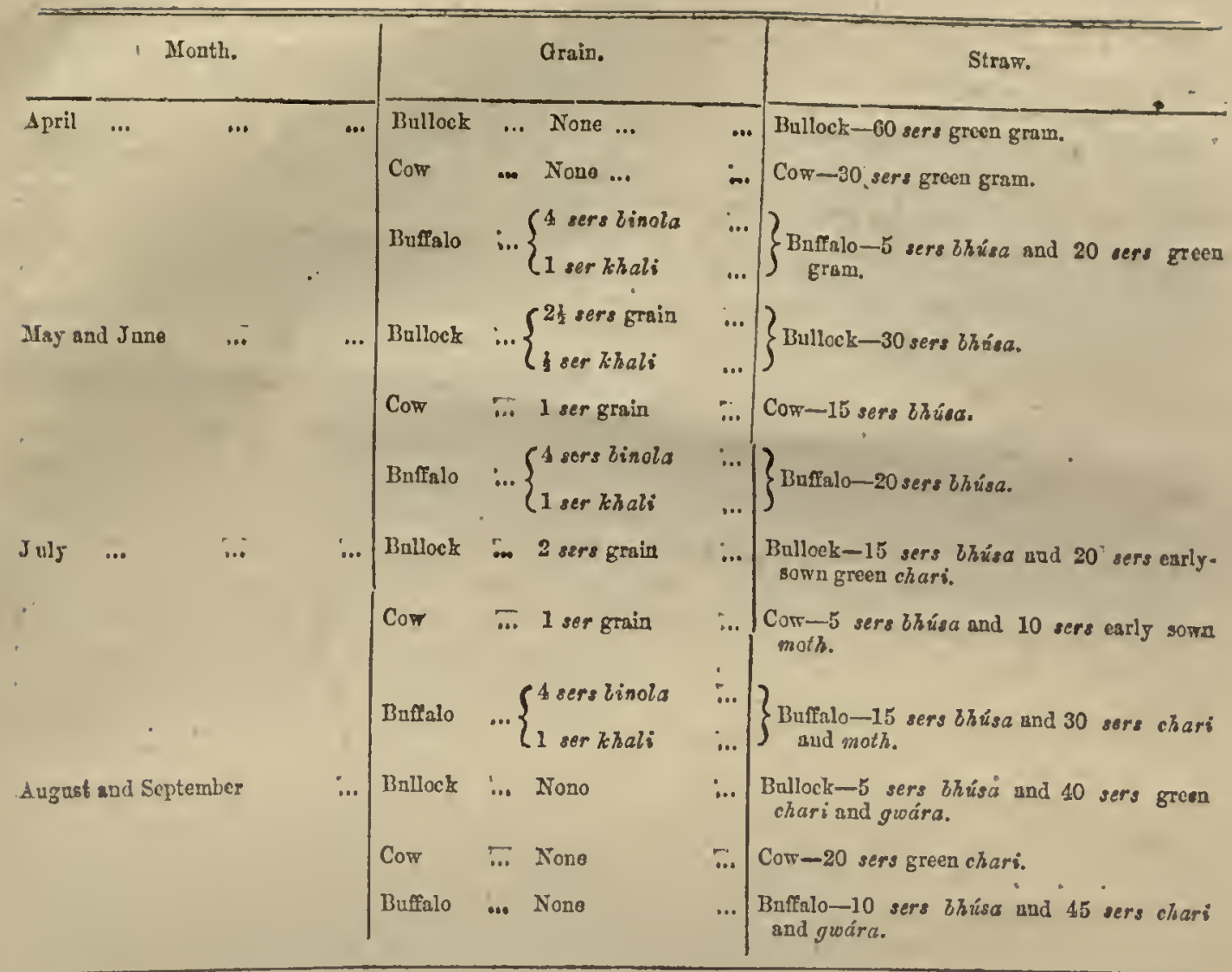

14. Rai Bahadur Hira Singh, Revenue Assistant of Gujrat, has supplied Gujrat. the following dictary for that district. It represents the food an ordinary small farmer rould give to his cattle. Nhilch kine get the first three items when in milk :-

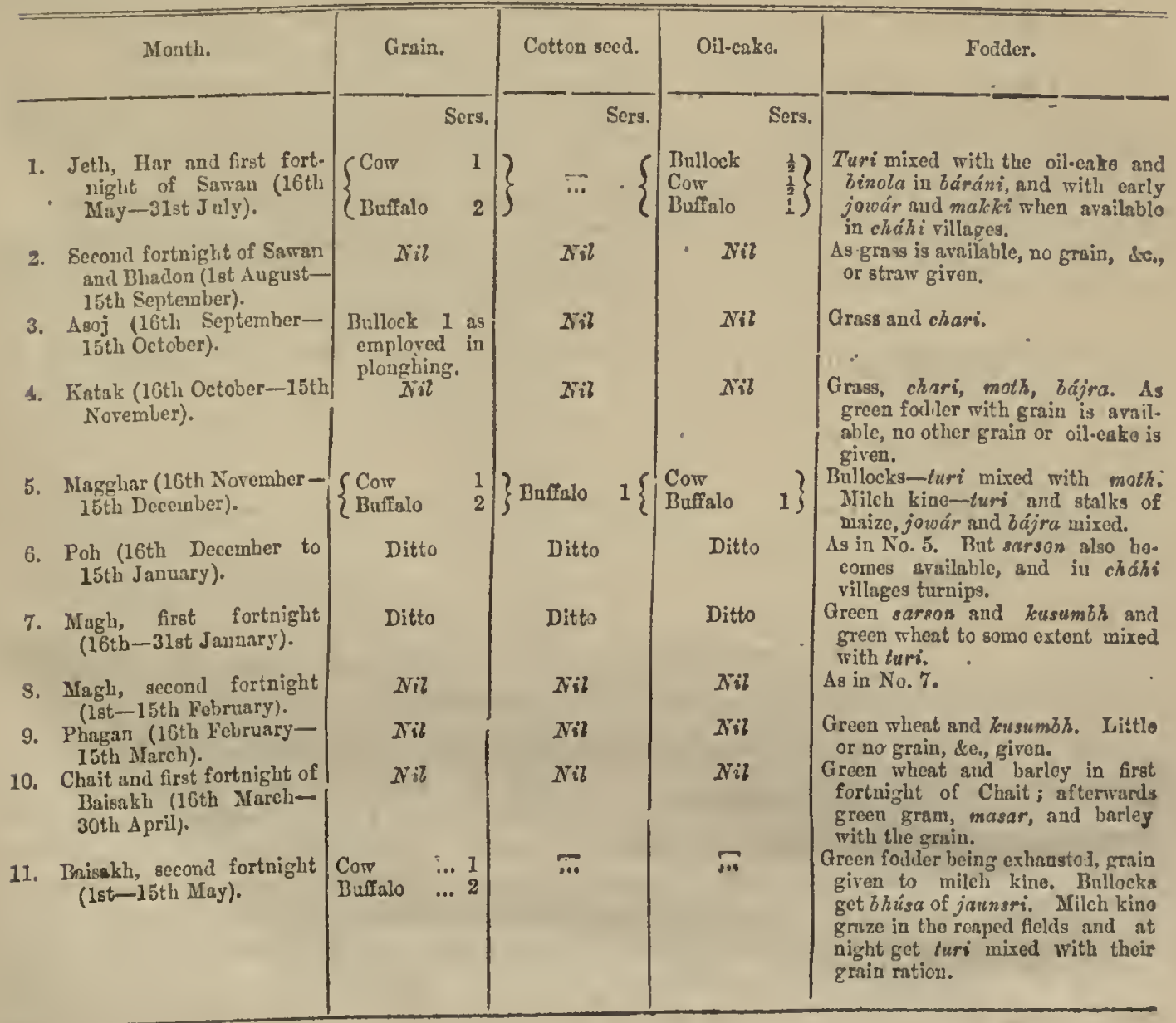


15. The livestock of the Rawalpindi distriet, both oxen and cows, is of very poor quality and little regarded.

Ramalpindi (Gazetteer) "In April, May and June plough bullocks get bhrisa or chopped straw, and while in work lalf a ser of kihal or oil-cake. Bullochs used as beasts of burden usually get a small feed of grain daily as well. In July and August they are fed on green grass, and from Sep. tember to March on the straw of autumn crops known as tánda (jovair and bajra) and missa (the straw of "moth). Favourite and valuable animals are also occasionally allowed to graze in jovair and moth fields when the crops are still young. Sarson and occasionally young wheat are also itsed as fodder for bullocks. In the hills more grass is used and less of other kinds of fodder."

16. When not in milk a cow is left to shift for herself pretty much, Montgomery (Purser: Settlement Roport, pares 46-8). going out with the cattle of the village to graze. However when in milk, if the owner is fairly off and she has not many rivals, she will get some boiled cotton seed (varenva), about $1 \frac{1}{4}$ ser per diem in Poh, and in Jeth and Har as much ground gram or barley soaked in water, and will in other respects be treated as her owner's bullocks, sharing with them and the buffaloes the oil-eake ( $k h a l)$ he may possess. As a rule a cow is well off, if she gets some chopped straw in addition to what she can pick up in the fields . . . . . . . . . . . . . Bullocks are fed four times a day, in the morning and evening, at noon, and before the'owner goes to bed. 'Lliey very seldom get any grain, if ever, but they may come in for some raw cotton seed in Poh. . . A bullock will eat from 12 to 15 sers of broken straw per diem, or about double that quantity of green fockler. Its food consists chicfly of broken straw of sorts, turnips, chari, green wheat, and dry jowás stallis. Its food during the year commeneing with Chaitr or the middle of March may be taken as follows:-

\begin{tabular}{|c|c|c|c|c|}
\hline haitr & "." & & $\ldots$ & Green wheat, methra, carrots (rare). \\
\hline Baisakh & ... & & $\ldots$ & $\begin{array}{l}\text { Wheat straw, dry turi, grazes in stubble } \\
\text { fields. }\end{array}$ \\
\hline ar & $\cdots$ & & $\ldots$ & $\begin{array}{l}\text { Ditto. If there has been rain, the } \\
\text { bulloeks are turned out to graze. }\end{array}$ \\
\hline awan-Bha & adon & & $\ldots$ & $\begin{array}{l}\text { Graze as before. If there has been no rain, } \\
\text { turi, chari or china sown in Jeth, and } \\
\text { kept orer is given. }\end{array}$ \\
\hline Asoj & $\because \cdots$ & & $\ldots$ & Kanigni straw or chari sown in Sawan. \\
\hline atak & $\cdots$ & & ... & $\begin{array}{l}\text { Chari sown in Sawan or straw of chinc } \\
\text { sown in Bhadon. Bullocks also graze } \\
\text { in stubble fields. }\end{array}$ \\
\hline Magghar & $\cdots$ & & ... & $\begin{array}{l}\text { Chari or china straw. Also rice straw, if } \\
\text { available. }\end{array}$ \\
\hline Poh & $\cdots$ & & ". & $\begin{array}{l}\text { Turi mixed with green wheat. Tops of } \\
\text { turnips. }\end{array}$ \\
\hline Magh & $\cdots$ & . & ... & $\begin{array}{l}\text { Turi mixed with grcen wheat and roots of } \\
\text { turnips. }\end{array}$ \\
\hline$\perp$ & $\ldots$ & & & $\begin{array}{l}\text { Green wheat, turnips and methres at the } \\
\text { end of the month. }\end{array}$ \\
\hline
\end{tabular}

. . It is not uncommon on the Ravi to turn the cattle out into the young fields of gram, massar, etc., to graze.

17. In an ordinary holding in this distriet the well cattle will be fed in Mnitan (Gazetteer, edition 1901-02, pages 225-26). April on peas or methra, and, as the wheat is cut, they get grazing in the stubble ; in May and June they graze in the wheat stubble or get fed on china or pea straw ; in July they get the early jowar and wheat straw is also arailable; from August to December they get joucár or green grass or bájra stalks, and when green food is not available, then wheat straw or dried jouter is given to them. With Deeember begins the turnip season, and as the turnips gire ont, green wheat is supplied as far as necessary, or the cattle receive peas ard 
methra until the wheat crop is eut in April. During a large part of the yent therefore the well eattle are stall-fed; and it is as a rule only when there is wheat stubble or peas or fresh grass on the ground that they get anything like sufficient grazing. In aldition to the peas, wheat, china, jowar, and turnips above mentioned there are several other crops used wholly or partly for fodder, such as rawain, másh, masar, gram, senji, methra, and swánk. Sometimes crops, such as jowar and turnips, shrivel up when young and become actually poisonous to cattle; this is ealled patha lagna. Cattle can graze freely among indigo plants, so long as they have not begun to seed, withont injuring the erop."

Multan and Muzaffargarh (based on a note by Rai Bahadar Tilok Chand).

18. The food of plough and well oxen is-

Haisakh and Jeth ...

While in milk a cow gets half a ser of oil-eake and a ser of grain, and a femalc buffalo double these quantities. In Poh and Magh when fed on turnips a cow gets a ser of binola and a milch buffalo 2 sers.

\section{CHAPTER II.-CEREALS.}

19. In temperate climates grasses or flowering plants of the natural Cereals and pulses. order Graminex oecupy the land to an cxtent far execeding any other elass of herbs. Probably plants of the order Leguminosæ occupy the second place. It is a striking fact that grasses (cereals) and leguminous plants (pulses) supply all that is neeessary to man and beast for fool except in very cold climates, and that the tro classes supplement each other, the element which is in defeet in most cereals being in exeess in the pulses. This ehapter and the next deal with the ccreals and pulses which supply food to cattle.

20. Zea mays : natural order Graminea.-For botanieal deseription see Makki, synonyms chalian, kukri, jowár (Jullundur). Fuller and Duthie's Field and Garden Crops of the North-Western Provinces, part $I$, page 21 , and plate $V$.

Chemical compasition of grain-

$$
\text { Per cent. }
$$

$\begin{array}{lllllr}\text { Water .. } & \ldots & \ldots & \ldots & \ldots & 12.5 \\ \text { Albuminoids } & \ldots & \ldots & \ldots & \ldots & 9.5 \\ \text { Starch... } & \ldots & \ldots & \ldots & \ldots & 70.7 \\ \text { Oil ... } & \ldots & \ldots & \ldots & \ldots & 3.6 \\ \text { Fibre ... } & \ldots & \ldots & \ldots & \ldots & 2.0 \\ \text { Ash ... } & \ldots & \ldots & \ldots & \ldots & 1.7\end{array}$

The dry stalks, karbi, are only indifferent fodder, and should be mixed with green food. Purser notes on page 178 of the Jullundur Gazettecr"when ripe the leaves and thinner parts of the stalk are fair fodder, but inferior to jowcir. - The harder parts of the stalk are rejected by cattle, and 
are good only for fuel and manure. The green plant is good fodder, and wellto-do zamindars sometimes sow maize thick like chari in order to supply green food to the cattle in the hot weather. "It is then sown very early in the hot weather." The area under maize in kharif 1910 was 1,206,645 acres, Tho districts having the largest acreage were-

$\begin{array}{lllllr} & & & & & \text { Acres, } \\ \text { Kangra } & \ldots & \ldots & \ldots & \ldots & 165,452 \\ \text { Hoshiarpur } & \ldots & \ldots & \ldots & \ldots & 161,149 \\ \text { Ambala } & \ldots & \ldots & \ldots & \ldots & 96,283 \\ \text { Jullundur } & \ldots & \ldots & \ldots & \ldots & 85,929 \\ \text { Sialkot. } & \ldots & \ldots & \ldots & \ldots & 79,234 \\ \text { Gurdaspur } & \ldots & \ldots & \ldots & \ldots & 72,992 \\ \text { Lyallpur } & \ldots & \ldots & \ldots & \ldots & 70,752\end{array}$

Jowár.

21. Sorghum vulgare : natural order, Graminece.-For botanical des: eription see Field and Garden Crops, page 25 , and plate VI,

Chemical composition of grain-

\begin{tabular}{lccccc} 
& & & & \multicolumn{2}{c}{ Per cent. } \\
Water & $\ldots$ & $\ldots$ & $\ldots$ & $\ldots$ & $12 \cdot 5$ \\
Albuminoids & $\ldots$ & $\ldots$ & $\ldots$ & $\ldots$ & $9 \cdot 3$ \\
Starch & $\ldots$ & $\ldots$ & $\ldots$ & $\ldots$ & $72 \cdot 3$ \\
Oil ... & $\ldots$ & $\ldots$ & $\ldots$ & $\ldots$ & 2.0 \\
Fibre ... & $\ldots$ & $\ldots$ & $\ldots$ & $\ldots$ & 2.2 \\
Ash ... & $\ldots$ & $\ldots$ & $\ldots$ & $\ldots$ & $1 \cdot 7$
\end{tabular}

Dr. Voelcker's analysis of the straw, which shows that it is more nour. isling than turnips (see paragraph 59), as given in Fịeld and Garden Crops, is as follows:-

\begin{tabular}{lccccr} 
& & & & \multicolumn{3}{r}{ Per cent. } \\
Water $\quad \ldots$ & $\ldots$ & $\ldots$ & & $\ldots$ & 85.17 \\
Flesh forming matters & $\ldots$ & $\ldots$ & & $\ldots$ & 2.55 \\
Fatty and heat producing matters & $\ldots$ & $\ldots$ & $11 \cdot 14$ \\
Inorganic matters ... & $\ldots$ & $\ldots$ & $\ldots$ & $1 \cdot 14$
\end{tabular}

If jowár is grown for grain, it is sown sparsely, 8 to 12 ser's of seed being used to the acre. If fodder (chari) only is wanted, 30 to 40 ser's will be used. In Gurgaon it is sometimes sown moderately thick so as to secure some grain as well as the chari, and then 15 ser's of seed go to the acre. Jowair is grown largely for grain in the five southern distriets of the Delhi division, and in some districts of the Multan division, especially Dera Ghazi Khan. Except in Dera Ghazi Khan the grain is little used as a food for cattle and horses. The dry stalks (tánda, karbi) are excellent fodder, and are usually chopped up and mixed with the bhiisa of kharif pulses, etc. In Lahore "if fodder is plentiful, the stalks are thrown down whole, and the cattle eat half, leaving the harder ends.' If owing to drought the plant withers, it is very dangerous for cattle, and to eat it may have fatal results. In Hissar the husks (boda), after the grain has been beaten out, are fed to cattle, mixed with pála. The stalks when green contain a good deal of sugar and are much appreciated as fodder. Part of the erop. is eut in October while still green. A variety known as "mithi jowár" is mentioned in the Gazetteer of the Lower Chenab Canal Colony, page 82 , "which is eaten with avidity by cattle, while its stalks are chewed like sugareane by the Janglis, who call it ganna (cane)." In some districts some jowar is sown thickly on irrigated land very early in the hot weather so as to secure a supply of green food in June and July. This is ealled Hári or Hárú. The ordinary sowing season is July. Owing to the way in which jowár is cultivated it is difficult to place very great reliance 
on the areas returned as under jowár and chari respectively. According to statement II the areas sown with jowar and chari respectively in kharif 1910
were-

$$
\begin{array}{ccccccc}
\text { Jowár } & \ldots & \ldots & \ldots & \ldots & \text { Acres. } \\
\text { Chari } & \ldots & \ldots & \ldots & \ldots, 342,870 \\
\text { firi } & \ldots & & \ldots & 1,485,345
\end{array}
$$

The figures under chari may include a certain amount of other fodder crops. The districts in which jowa's is grown largely for grain are the five southern districts of the Delhi division, Ferozepore, the districts of the Rawalpindi division (except Jhelum), north of the Salt Range, Jhang, Multan, and
Dera Ghazi Khan.

Sorghum halepense - baru-is a fodder grass which when it dries up has the same poisonous properties as its cultivated relation (Fodder Grasses of Northern India, pages 40-41).

22. Pennisetum typhoideum : natural order, Graminea.-For botanical

Bájra, oynonym bájri. description see Field and Garden Crops, part I, page 30 , and plate VII.

Chemical composition of unhusked grain-

$\begin{array}{lccccc}\text { Water } & \ldots & \ldots & \ldots & \ldots & 11.3 \\ \text { Albuminoids } & \ldots & \ldots & \ldots & \ldots & 10.4 \\ \text { Starch } & \ldots & \ldots & \ldots & \ldots & 71 \cdot 5 \\ \text { Oil } \ldots & \ldots & \ldots & \ldots & \ldots & 3.3 \\ \text { Fibre ... } & \ldots & \ldots & \ldots & \ldots & 1.5 \\ \text { Ash ... } & \ldots & \ldots & \ldots & \ldots & 2.0\end{array}$

The grain is considered excellent food for men, and in Gujrat some of it is given to bullocks. As fodder the stalks are distinctly inferior to those of jowár, and in some parts, if other fodder is abundant, only the heads are cut off and the stalks are left standing. In Karnal they are called dandar and in Hissar karbi. They are chopped up and given to the cattle mixed with green stuff or with gram áta. Before the Sirsa Branch of the Western Jumna Canal began to irrigate the southern part of the Kaithal tahsil, it used to be a common sight there to see in the barani fields large ricks (chhor) of bájra stalks black with age preserved as a reservo against fodder famines. In some of the northwestern districts the stalks of bájira are a very important part of the fodder supply.

The area returned as under bájra in kharif 1910 was 2,412,497 acres: Of this 1,173,585 acres were in the Hissar, Rolitak and Gurgaon districts of the Delhi division, Hissar alone accounting for nearly 700,000 acres, and 792,106 acres were in the six districts of the Rawalpindi division.

Bájra is a near relation of anjan or dháman (Pennisetum cenchroides); the best of the uncultivated fodder grasses in the Punjab.

23. Setaria Italica : natural order, Graminea.-For botanical descripFangni, synonym kanni (Simla). tion see Field and Garden Crops, part II, page 5, and plate XXV.

The chemical composition of the husked grain is-

\begin{tabular}{lcccrr} 
& & & & \multicolumn{2}{c}{ cent. } \\
Water & $\ldots$ & $\ldots$ & $\ldots$ & $\ldots$ & $10 \cdot 2$ \\
Albuminoids & $\ldots$ & $\ldots$ & $\ldots$ & $\ldots$ & $10 \cdot 8$ \\
Starch & $\ldots$ & $\ldots$ & $\ldots$ & $\ldots$. & $73 \cdot 4$ \\
Oil & $\ldots$ & $\ldots$ & $\ldots$ & $\ldots$. & $2 \cdot 9$ \\
Fibre & $\ldots$ & $\ldots$ & $\ldots$ & $\ldots$ & $1 \cdot 5$ \\
Ash & $\ldots$ & $\ldots$ & $\ldots$ & $\ldots$ & $1 \cdot 2$
\end{tabular}

This inferior kharif millet is grown more or less in all districts, but except in the hills and submontane tracts and in parts of the Multan difision. 
the areas are generally insignifieant. Mr. Purser wrote on page 115 of the Montgomery Settlement Report :-

"Two varieties of this crop are recognized, kangan and kangni, but they differ only ix size, as kangan is larger and eoarser than kangni. Kangan is rare. The straw . . . is called parál or paráli. It is not broken up like turi. It is considered good strengthening food. The grain : . . is used as an article of diet."

In Jhang "patehes are grown on wells for fodder by zamindar's who keep liorses, but the grain is seldom threshed." In Lahore kangni is grown sometimes for fodder and sometimes for grain, and the fodder is considered good. In the Simla Hills it is sown in poor lands, and the grain is boiled and eaten like rice, while the straw is fed to cattle during the winter.

24. Panicum miliaceum: natural order, Gramince.-For botanical Chíns. description sce Field and Garden Crops, part II, page 1, and plate XXIII.

The chemical composition of the husked grain is -

Per cent.

Tater
Albuminoids
Starch
Oil
Fibre
Ash

$\begin{array}{cc}\ldots & \ldots \\ \ldots & \ldots \\ \ldots & \ldots \\ \ldots & \ldots \\ \ldots & \ldots\end{array}$

$\begin{array}{ll}\cdots & \cdots \\ \cdots & \cdots \\ \cdots & \cdots \\ \cdots & \cdots \\ \cdots & \cdots \\ \cdots & \cdots\end{array}$

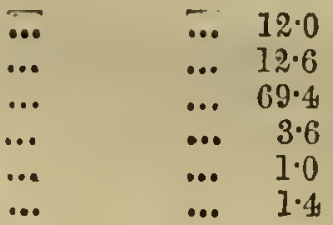

Outside the hills and one or two of the south-wrestern districts this is: a very unimportant crop. As regards its cultivation in Jhang and Multan the: following extracts may be given-

\section{Steedman's Settlement Report of Jhang, page 94-}

"China as a crop is largely grown on well lands. Two crops are reaped in the year, the first in Jeth and Har, the second in Magghar . . . China requires a large quantity of water . . . . The first china erop is used cbiefly as fodder. It is very rarely threshed. The second china crop comes in useful for the wheat sowings. The crop is sometimes pulled up or cut half ripe, as much grain beaten out as can be, and the straw used for fodder. More generally the second erop is allowed to ripen . . . If there bave been good lains and grass is plentiful, the whole of the china will be allowed to ripen; if there bas. been but little rain and grass is scant, the wbole erop may be used as fodder."

\section{Multan Gazetter, edition of 1901-02-}

"China is a crop wbich has nearly trebled in area since 1880 and now represents: 1.5 per eent. of the cropping of the district. This increase is entirely due to its popularity on the sidhnai Canal, where it has been extensively grown both in the zaid rabi and in the kharif harvest, about one-third being shown in the revenue records against the former

- 'The crop is mainly used for food, but a certain portion of the zaid rabi is employed as fodder also. As a food the grain is inferior . . . It provides the poorer classes with a cheap if somewhat distasteful food."

In Simla the straw is fed to cattle in the winter. In 1910-11 the area under kangni and china amounted to about 56,000 acres, china being the more important crop. The only districts in which the area under kangni execeded 1,000 acres were--

Acres.

\begin{tabular}{|c|c|c|c|c|c|}
\hline Sialkot & $\ldots$ & $\ldots$ & ... & $\cdots$ & 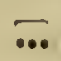 \\
\hline angra & $\ldots$ & " & ... & • & . \\
\hline Rawalpindi & .. & ..• & $\ldots$ & $\because$. & ... \\
\hline
\end{tabular}

25. Panicum frumentaceum : natural order, Graminea.-For botanical: Sánwak, synonym swánk, samrikha, jhandru (Kangra). deseription see Field and Garden Crops, part II, page 3, and plate XXIV.

For chemical composition of unhusked grain see Church's "Food-grains: of India," page 49. 
In Gujrat kangni and suánk are mixed with maize erops on well lands and ripen before the maize.

In Jhang sámeak is grown to a small extent for horse fodder on wells: In Muzaffargarh it is grown on eanal and well lands, mostly as a food crop, but it is sometimes used green for fodder. This millet is also grown in hill districts. In the Dictionary of Eeonomic Products, volume VI, part I, page 9, the quick-growing sailáb erop, scmúlkha, sown in Jhang, MLianwali and Muzaffargarli in land newly left by the river, is treated as the same plant as sánvak, but possibly this may be a mistake. Pandit Hari Kishan Kaul, has informed me that the main differenee is that samukha has a black seed, while that of samwati is white. Samukha may perliaps be one of the panicums mentioned below. The account of its cultivation giren on page $\mathbf{1 0 6}$ of the Muzaffargarh Gazetteer may be quoted:-

"As the rivers reeede in August and September they leave large flats of yuicksand or rather quiek-mud, which will not support a man. The sower taking a ghara of seel cnter as the mud, supporting himself on the ghara, and scatters the seed over the mud. As the mud dries the plant springs up and produces grain in Oetober. The grain is small and inferior. Kirars eat it on fast days. The straw is considered excellent fodder."

Scmitich is grown mostly for fodder. The crop returns for 1910-11 show 2,500 acres as under sinuck in Gujranwala and 1,019 in Gujrat. In Kangra sánwak is included in an area of 14,475 acres shown as under "Other cereals." Jlang returned 2,453 acres of sánwak and 491 of samikiha, Mianwali 46 of sánwak and 504 of samúkha, and Muzaffargarl 790 of scmúliha.

The wild grass, sannuak-Panicum colonum, is useful fodder when it is young, and Hinclus eat the grain on fast days (Hissar Gazettecr, page 10, and Karnal Gazctteer, edition of 1890, page 22). Panieum crus-galli, called bharti in the Hissar district, is also a fodder grass. If the crop described as shumalh in the crop returns of the Hoshiarpur district, and which there occupied in kharif 1910 an area of 3,146 aeres, is not Panieum frumentaceum, it may be a cultivated variety of one of these wild panicums.

26. Panicun helopus: natural order, Graminea.-For botanieal description see Duthie's "Fodder Grasses of Northern India," page 8. Duthie states Kuria. that it is an excellent fodder grass for both horses and cattle, and that it is up to about 5,000 feet. It is cultivated to a small extent on well lands in Jhang and Muzaffargarh, and is uscd as fodder for horses.

27. Panicum jumentorum, a native of tropieal Afriea, is a rich fodder grass. It is best propagated by dividing Grinea grass. the roots. It has been cultivated experimentally in the Punjab, but has not become an established fodder crop.

28. Oryza sativa: natural order, Graminea.-For botanieal deseription see Ficld and Garden Crops, part I, page 15, and plate IV.

Chemical eomposition of husked grain is-

Per cent.

\begin{tabular}{lrrrrrr} 
Water & $\ldots$ & $\ldots$ & $\ldots$ & $\ldots$ & $\ldots$ & $12 \cdot 5$ \\
\multicolumn{2}{l}{ Albuminoids } & $\ldots$ & $\ldots$ & $\ldots$ & $\ldots$ & $7 \cdot 3$ \\
Stareh & $\ldots$ & $\ldots$ & $\ldots$ & $\ldots$ & $\ldots$ & $75 \cdot 3$ \\
Oil & $\ldots$ & $\ldots$ & $\ldots$ & $\ldots$ & $\ldots$ & $\cdot 6$ \\
Fibre & $\ldots$ & $\ldots$ & $\ldots$ & $\ldots$ & $\ldots$ & $\cdot 4$ \\
Ash & $\ldots$ & $\ldots$ & $\ldots$ & $\ldots$ & $\ldots$ & .6
\end{tabular}

The straw is called paral or parali. It is not threshed with the grain. As fodder the straw is very poor, but in rice tracts it is given to the cattle faute de mieux. It ought to be reinforced with green stuff. In Karnal the parali of 
the coarse santhi rice is said to be better fodder than that of the fine ziri rice. It is noted that when, owing to want of water, the crop produces no grain, the straw, which is then known as marain, is an "excellent fodder" (Hissar Gazetteer, page 173). The area under the many varieties of riec was returned in kharif 1910 as 712,843 acres. The districts having the largest acreage under this crop were--

$\begin{array}{lllllr} & & & & & \text { Acres. } \\ \text { Kangra } & \ldots & \ldots & \ldots & \ldots & 119,995 \\ \text { Sialkot } & \ldots & \ldots & \ldots & \ldots & 64,800 \\ \text { Dera Ghazi Khan } & \ldots & \ldots & \ldots & \ldots & 63,588 \\ \text { Ambala } & \ldots & \ldots & \ldots & \ldots & 61,984 \\ \text { Gujranwala } & \ldots & \ldots & \ldots & \ldots & 59,606 \\ \text { Gurdaspur } & \ldots & \ldots & \ldots & \ldots & 50,707 \\ \text { Muzaffargarh } & \ldots & \ldots & \ldots & \ldots & 47,963 \\ \text { Karnal ... } & \ldots & \ldots & \ldots & \ldots & 47,153\end{array}$

29. Eleusine coracana : natural order, Graminea.-For botanical descripMandwa, synonyms, mandal, koda, chalodhra (Guj. tion seo Food and Garden Crops, part II, rat), mandan (small varicty). page 10, and plate XXVIII. Chemical composition of husked grain-

Per cent.

$\begin{array}{lcccccr}\text { Water } & \ldots & \ldots & \ldots & \ldots & \ldots & 13 \cdot 2 \\ \text { Albuminoids } & \ldots & \ldots & \ldots & \ldots & 7 \cdot 3 \\ \text { Starch } & \ldots & \ldots & \ldots & \ldots & \ldots & 73 \cdot 2 \\ \text { Oil } & \ldots & \ldots & \ldots & \ldots & \ldots & 1 \cdot 5 \\ \text { Fibre } & \ldots & \ldots & \ldots & \ldots & \ldots & 2 \cdot 5 \\ \text { Ash } & \ldots & \ldots & \ldots & \ldots & \ldots & 2.3\end{array}$

Under the name of ragi it is largely grown as a food crop in Southern India. The total area in the Punjab in kliarif 1910 was returned as 22,035 acres, and two-thirds of this came from the hill districts of Kangra and Simla. The only other districts with areas exceeding 1,000 acres were Karnal $(1,220)$, Sialkot $(1,444)$, and Rawalpindi $(1,460)$. The grain is very inferior food, but useful to poor people. According to the Simla Gazetteer, page 66, the straw is fed to cattle and "is said to be very sweet." In Karnal its cultivation as a dry crop expands a good deal in dry seasons, as it is sown in fields intended for the finc zivi rice, when the latter cannot be planted out owing to the drought. There "the blius is very bad fodder, and is gencrally burnt as it stands or grazed down" (Gazetteer, edition of 1890, page 204). The wild grass, Eleusine flagellifera, which is the chiimbar of the Western Punjab, and the gathil of Karnal, is a useful fodder plant. Other wild species of eleusine, which are fodder grasses, will be found noted on pages 56.9 of Duthic's "Fodder Grasses of Northern India."

30. Paspalum scrobiculatum : natural order, Graminece-For botanical Inodra. description see Field and Fodder Crops, part II, page 8, and plate XXVII. The chemical composition of the husked grain is given on page 40 of the "Food Grains of India."

This poor millet is a favourite crop in parts of the United Provinces and is grown there on inferior outlying lands. It appears to be grown to some extent in the Simla Hills and elsewhere (Punjab Produets, page 238), and may be confused in our returns with koda (Eleusine coracana). In the list of crops on page 116 of the Hoshiarpur Gazetteer manclal (Eleusine coracana) and kodr'a are shown separately, but the botanical name of kodra is also given as Eleusine coracana. It is stated on page 1 of Duthie's "Fodder Grasses of Northern India" that the grain is chiefly consumed by the lower elasses, and that the straw is used as fodder. 
31. Triticum sativum : natural order, Graminece-For botanieal des-

Kanak, synonym gehun (in eastern districts). cription see Fuller and Duthic, Food and Garden Crops, part I, page 1 , and plates I-A and I-B.

The arerage chemical composition of the grain of Indian wheats is-

\begin{tabular}{lcccccc} 
Water & $\ldots$ & $\ldots$ & $\ldots$ & & \multicolumn{2}{c}{ Per cent. } \\
Albuminoids & $\ldots$ & $\ldots$ & $\ldots$ & $\ldots$ & 12.5 \\
Starch & $\ldots$ & $\ldots$ & $\ldots$ & $\ldots$ & $\ldots$ & 135 \\
Oil & $\ldots$ & $\ldots$ & $\ldots$ & $\ldots$ & $\ldots$ & $68 \cdot 4$ \\
Fibre & $\ldots$ & $\ldots$ & $\ldots$ & $\ldots$ & $\ldots$ & 1.2 \\
Ash & $\ldots$ & $\ldots$ & $\ldots$ & $\ldots$ & $\ldots$ & 2.7 \\
\end{tabular}

The grain is too valuable to be used much as food for eattle.

It is sometimes given to milch kine. The uses as fodder of the dry broken straw or turi have already been indieated. The ways in which it is stored may be gathered from the following extraets:-

Karnat Gazetteer, edition of 1890, paragraph 222.- "Bhis is stored in a kup made of a wisp of straw wound spirally round and round upon a foundation of cotton stems so as to form a high circular reeptacle in which the bhis is packed and preserved, and thatehed when full. A long low stack fenced in by cotton stems alone is called a chhan or bhrisari. Near the eity the people store their bhics in mud receptacles (khutck) and plaster it all round the top. The bhis is taken out from a hole at the bottom as wanted."

Chenab Colony Gazetteer, page 80.-Bhuisa "is stored in stacks, músal, or in low heaps, dhar. The misct is built up in the form of a haystack and better withstands the rain orving to its sloping thateh. But the dhar is often preferred because it is less exposed to damage from fire. An enemy can burn a misal down, whereas a dhar will only smoulder at one end."

Multan Gazetteer, page 219.- "The wheat straw is collected in stacks, palle, and surrounded with wattles or cotton stalks and daubed over with mud."

Near towns the green wheat when in ear (khawid) is eut down and fetches a very good price. In some of the western districts much wheat on the wells is cut down green to feed the bullocks, the amount which has to be sacrificed depending of course on the nature of the season.

Thus the late Mrr. Steedman wrote in paragraph 131 of the Jhang Settlement Report :-

"Praetically the tenant can cut as mueh green wheat and jowair to feed the well bullocks as is neccssary. There is really no limit. Similarly, the whole of the turnip erop is his. It is only where the crop or roots are sold that the proprietor takes a share; otherwise all (of the fodder) that he takes is a marla or two of green wheat and a bundle or two of turnips."

In rabi 1910 the area under wheat was 8,884,697 acres, distributed among the divisions as follows:-

\begin{tabular}{|c|c|c|c|c|c|c|c|c|}
\hline \multicolumn{7}{|c|}{ Division. } & Aeres. & $\begin{array}{l}\text { Per cent. of total } \\
\text { cropped aren of } \\
\text { both harvests. }\end{array}$ \\
\hline $\begin{array}{l}\text { Delhi ... } \\
\text { Jullundur } \\
\text { Lahore .... } \\
\text { Rawalpindi } \\
\text { Ninltan ... }\end{array}$ & $\begin{array}{l}\ldots \\
\ldots \\
\ldots \\
\ldots\end{array}$ & $\begin{array}{l}\cdots \\
\cdots \\
\cdots \\
\cdots \\
\cdots\end{array}$ & $\begin{array}{l}\cdots \\
\cdots \\
\cdots \\
\cdots\end{array}$ & $\begin{array}{l}\cdots \\
\cdots \\
\cdots \\
\cdots \\
\cdots\end{array}$ & $\begin{array}{l}\cdots \\
\cdots \\
\cdots \\
\cdots \\
\cdots\end{array}$ & $\begin{array}{l}\ldots \\
\ldots \\
\cdots \\
\cdots\end{array}$ & $\begin{array}{r}892,521 \\
1,662,321 \\
2,024.376 \\
2,127,265 \\
2,178,014\end{array}$ & $\begin{array}{l}11 \cdot 8 \\
29 \cdot 9 \\
39 \cdot 5 \\
13 \cdot 7 \\
10 \cdot 8\end{array}$ \\
\hline & & & & Total & ... & $\ldots$ & $8,884,697$ & $31 \cdot 1$ \\
\hline
\end{tabular}

These figures show the enormous importanee of wheat straw as a souree of fodder in the three western divisions. 
32. Hordeum vulgare : natural order, Graminea.-For botanieal desJau. cription of barley see Field and Garden The chemical analysis of the husked grain iscrops, part I, page 9, and plate II.

\begin{tabular}{|c|c|c|c|c|c|c|}
\hline Watcr & $\ldots$ & ... & $\ldots$ & ... & $\ldots$ & $\begin{array}{l}\text { er cent. } \\
12.5\end{array}$ \\
\hline \multicolumn{2}{|c|}{ Albuminoids } & $\ldots$ & $\ldots$ & $\ldots$ & ... & $11 \cdot 5$ \\
\hline Starch & $\cdots$ & $\ldots$ & $\ldots$ & $\ldots$ & $\ldots$ & $70 \cdot 0$ \\
\hline Fat & $\ldots$ & ... & $\ldots$ & ... & ... & $1 \cdot 3$ \\
\hline Fibre & ... & ... & ... & $\ldots$ & $\ldots$ & $2 \cdot 6$ \\
\hline Ash & $\ldots$ & ... & $\ldots$ & $\ldots$ & $\ldots$ & $2 \cdot 1$ \\
\hline
\end{tabular}

Barley is, speaking generally, a much more important crop in the cis-Sutlcj than in the trans-Sutlej districts. $A$ s an nnirrigated crop it is often grown mixed with wheat, gram, or masri. There is a beardless rariety known as paighambari or Kabuli. Barley can be sown much later than wheat, in some of the western districts as late as the middle of January, and, except when sown late, it ripens much carlicr. Hence it is useful to supply tenants and the poorer landowners with food before wheat becomes available. The grain is also commonly given to liorses. Purser quotes a Montgomery proverlb-

"Jau kache, pakke, daddare, jo joban turiyån."

"Uuripe, ripe, half ripe barley, whatever excellence it possesses is only for horses."

The dry straw or turi is an excellent fodder uscd in the same may as wheat. Being less valuable than wheat a greater proportion of the barley grom is used for green fodder. It is sometimes sown for this purpose with other fodder crops in cotton ficlds while the cotton is still standing.

The area under barley in rabi 1911 was 1,003,429 acres. In Hissar and Gurgaon it cover's a much larger acreage than wheat. The crops with the largest areas were-

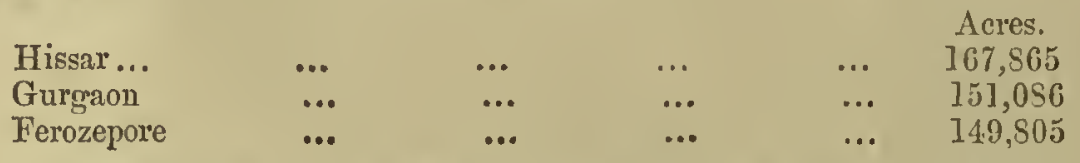

The next largest areas were in Sialkot $(59,147)$ and Kangra $(54,956)$.

33. Avena sativa: natural order, Graminece.-For botanical description. Jawi : synonym jai. sec Field and Garden Crops, part I, page 13 , and plate III.

Oats have been introduced into the Punjab and are cultivated to a small extent for green fodder.

The wild oats, gandal (Avena fatua), sometimes seen in wheat fields, is an introduced weed, which is considered good fodder in California (see Duthie's Fodder Grasses of Northern India, page 51).

\section{CHAPTER III.-PULSES.}

34. The value of pulses as food for eattle is enormous, and the extent to Value of mixed crops of cereals and pulses. which they are grown alone or mixed with cercals, cotton, ete., is a marked feature of the agriculture of the Punjab. The value of the practice of sowing pulses with other crops is great. An excellent statement of the case will be found on pages 141-43 of Moreland's "Agriculture of the United Prorinces." Briefly it may be summed up as follows :-

(a) Insurance.-The pulses generally want less moisture than the crops whose companions they are, and gram, or mash, or múng may survive when wheat, or cotton, or joúar has dried up. 


\section{7.}

(b) Checking of evaporation from the soil, the low growing ereeping pulses, shading the "surface.

(c) Leguminous plants like pulses feed the soil with nitrogen.

(d) The produce of mixed crops of wheat and gram or barley and gram are reaped together. The grain is not separated but' ground together, and the resulting flour is an excellent food.

35. The kharif pulses with the exception of grodr belong to the Kharif pulses.

sub-division Phaseolæ of the natural order Leguminosæe, and the three prineipal ones, moth, másh and ming are included in the genus Phaseolus, from which the sub-division takes its name. Givár belongs to the same natural order, but to a different sub-division, Jalegex.

36. Cyamopsis Psoralioides : natural order, Leguminosa.-For botanical Gwír, synonym gwára. description see Fuller and Duthie's Field and Garden Crops, part II, page 24, and plate XXXV.

It is an important fodder erop in the districts of the Punjab formerly included in the United Provinces. It is suited to light sandy soil, and is usually sown alone, but is sometimes mixed with bajjra. It is considered to be a good erop to follow cotton or chari, becanse " the leaves appear to act as manure on tlie soil and to prepare it for a subsequent rabi" (Hissar Gazetteer, page 170). No doubt, like other leguminous erops, it feeds the soil with nitrogen. The grain is very rich in albuminoids, the chemical composition being --

\section{Per cent.}

$\begin{array}{lcccccc}\text { Water } & \ldots & \ldots & \ldots & \ldots & \ldots & 11 \cdot 3 \\ \text { Albuminoids } & \ldots & \ldots & \ldots & \ldots & \ldots & 29 \cdot 8 \\ \text { Starch } & \ldots & \ldots & \ldots & \ldots & \ldots & 46 \cdot 2 \\ \text { Oil } & \ldots & \ldots & \ldots & \ldots & \ldots & 1 \cdot 4 \\ \text { Fibre } & \ldots & \ldots & \ldots & \ldots & \ldots & 7 \cdot 7 \\ \text { Ash } & \ldots & \ldots & \ldots & \ldots & \ldots & 3 \cdot 1\end{array}$

But it is considered coarse and produces flatulence, and both grain and leaves and stalks are given to the bullocks. The grain is either boiled or coarsely ground and given dry. The dry straw is useless, but the green plant is cut and ehopped up and given to bullocks. The broken pods, called palosi, left on the threshing floor, make good fodder.

After gram, gucir is the most important pulse in Rohtak, Gurgaon and Delhi. The arerage in these three districts in 1910-11 was -

$$
\begin{aligned}
& \begin{array}{llllllll}
\text { Delhi } & \ldots & \ldots & \ldots & \ldots & \ldots & 37,079
\end{array} \\
& \begin{array}{lllllll}
\text { Rohtak } & \ldots & \ldots & \ldots & \ldots & \ldots & 59,079 \\
\text { Rohthen } & \ldots & \ldots & \ldots & \ldots & \ldots & 5,825
\end{array} \\
& \begin{array}{llllll}
\text { Gurgaon } & \ldots & \ldots & \ldots & \ldots & \ldots 6 \\
& \ldots & \ldots & \ldots & \ldots & \ldots 7,138
\end{array}
\end{aligned}
$$

37. Cajanus Indicus; var. bi-color : natural order Leguminosa.-For botanieal deseription see Ficld and GarArhar, synonyms dángrí (Gujrat), bhárt (Simla), den Crops, part II, page 20, and plate dhíngra, kúndí (Kíangra). XXXIV.

The chemieal composition of the unhusked grain is similar to that of gram, but it is difficult to digest-

$\begin{array}{lcccccc}\text { Water } & \ldots & \ldots & \ldots & \ldots & \ldots & 13 \cdot 3 \\ \text { Albuminoids } & \ldots & \ldots & \ldots & \ldots & \ldots & 17 \cdot 1 \\ \text { Starch } & \ldots & \ldots & \ldots & \ldots & \ldots & 55 \cdot 7 \\ \text { Fat } & \ldots & \ldots & \ldots & \ldots & \ldots & 2 \cdot 6 \\ \text { Fibre } & \ldots & \ldots & \ldots & \ldots & \ldots & 7 \cdot 5 \\ \text { Ash } & \ldots & \ldots & \ldots & \ldots & \ldots & 3.8\end{array}$

In the United Provinees this tall pulse is a very important fodder erop and is usually grown mixed with jowár, bájra, or cotton. The cultivation and uses 
of arhar in the United Provinces aro described on pages 200-202 of Morland's "Agriculture of the United Provinces." The following may be quoted :- ,

"When arhar is sown with eotton it is usually plaeed in lines about fifteen foet apart; it grows thick and high...and! it is of particular value as a shelter; the outturn from a cotton field, is not, however, as great as from a millet field, as the arthar plants are far fewer in number ...Arhar seems to survive any deficieney of rain short of an absolute drought, and is almost independent of cold weather rain; while nothing short of regular floods seems to injure it seriously, but it has dangers of its own. The greatest is frost to which the plant is more liable than any other of our field crops : a single ground frost may destroy the entire crop. The caterpillar, known usually as chherda, does a good deal of harm in some seasons, boring into the pods and eating the young seeds......The dry leaves and pods make most nourishing food for cattle and the stalks are put to a great variety of uses, the chief of which is lining temporary wells."

Though sown with cotton, the grain, if it has survived the cold, does not ripen till the beginning of the hot weather. Its great susceptibility to frost makes it unsuited to the climate of most parts of the Punjab, and it is an unimportant crop except in the east of the Gurgaon district, where it is sown in lines with cotton. The leaves are used for fodder, and the stalks for fuel, while " the pulse is little esteemed, so that its perishing in the winter is of the less consequence " (Gurgaon Gazetteer, page 93). The variety which ripens in the autumn and is occasionally sown in Gurgaon seems to be the plant known as thur in the United Provinces (Cajanus Indicus, var. flavus).

38. Phaseolus mungo; var. radiatus : natural order, Leguminosc.-For Másh, synoynms urd, máh, máhri (inferior variety). botanical description see Field and X. Garden Crops, part I, page 39, and plate $\mathrm{X}$; also Church's "Food Grains of India," page 148 .

Chomical composition of unhusked grains :-

Per cent.

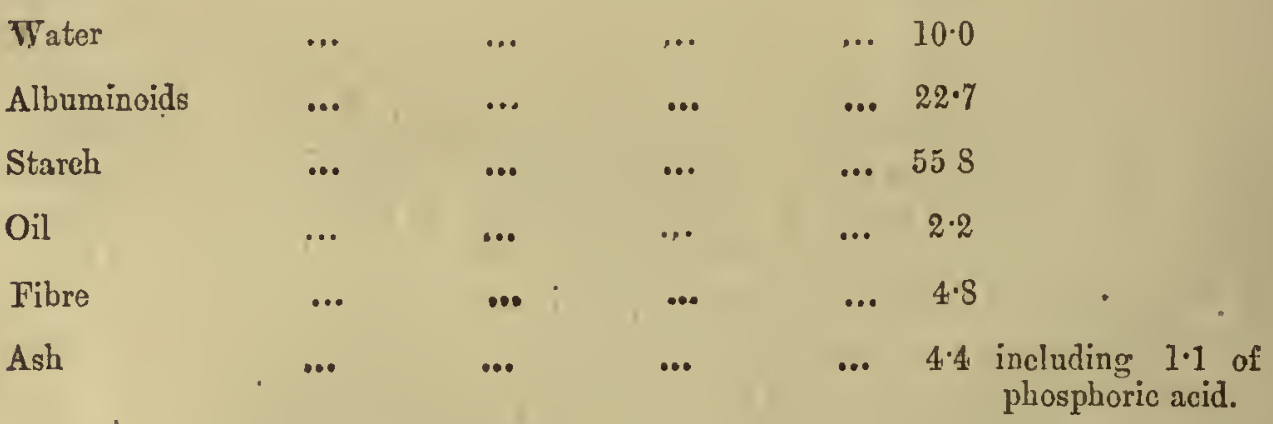

This crop and its two relations, mung (Phaseolus mungo) and moth (Phaseolus aconitifolius) form a group of kharif pulses of great importance as furnishing food for men and cattle. According to Purser there are two rarieties of másh, one with black seeds known as burang, and one with green called kachria. "The former grows as a creeper along the ground; the latter upright. The pods of burang are blackish purple, long and thin; those of kachú greenish yellow, short and thick......the dal of kachía is larger, has a better taste, and requires less time in cooking than that of burang, hence it sells at 3 or 4 scers the rupee dearer" (Settlement Report of Montgomery, page 117).

Ifásh is sown either alone or mixed with jowar, cotton, or with other pulses such as mung, kulath, or rawan. It is unsuited to a light sandy soil in upland tracts, and is therefore not grown with bajro. In Jullundur it is mostly found in the best class of dry land and often precedes sugarcane. It is the one of the pulses which is grown most in riverain tracts and in the low hills. In Kangra it is sown on the ridges between rice fields or mixed with 7ulath. It does best in a season of moderate rainfall, and is often destroyed by heavy rain or by floods in the autumn. "The fodder obtained from moth, muing and másh is divided into three kinds, which ranked according to their value, are-the empty pods.(phali), leares (patti), and the stalks (gona). The 
last are of little use for cattle and are sold to owners of asses and mules, when possible. The leares are first stripped off by hand, then the stalks and pods are threshed, next the stalks are picked out, and then the remainder is winnowed and the ehaff separated from the grain. As regards their ralue as fodder, moth stands first, másh sccond, and ming last (Purser, quoted on pages 186-87 of Jullundur Gazetteer). Mlish is a good fodder for camels."

39. Phaseolus mungo : natural order, Leguminosc.-For botanical desMúng, synonym múngli, an inferior varicty in La. cription see Fuller and Dutlie's Food dhisna.

To quote from the same book:and Garden Crops, part I, page 87 , and plate IX.

"Ilüng is one of four pulses which resemble one another very closely in appearanee and habit of growth, the other three being urd or másh, lobia, and moth. Mrung is the most valuable of the four, and as a rule its consumption is confined to the better class of natives. It can be easily distinguished from either moth or lolia, but its resemblance to urd is so close that both are considered by some botanists varieties of the same species. The most popular distinction between the two plants in the field lies in muing having dark green and urd yellowish green leaves, but the prineipal difference is in the shape of the grain in that of urd being mueh larger and longer than that of $m$ úng. . . . There are three well marked varieties of ming having respectively green, yellow, and black seeds. The green seeded is the typical and commonest variety, that with yellow seed, known as sona or golden múng, being named phaseolus aureus, and that with black seeds phaseolus max."

According to Purser the variety with black seeds is ealled burang or minga, and the green and yellow seeded varieties mingi.

The chemical composition of the unhusked grain is-

\begin{tabular}{|c|c|c|c|c|c|}
\hline & & & & $\begin{array}{l}\text { er cent. } \\
10.8\end{array}$ & Per cent. \\
\hline Albuminoids & $\cdots$ & $\begin{array}{l}\cdots \\
\ldots\end{array}$ & ?. & $\begin{array}{l}10 \cdot 8 \\
22 \cdot 2\end{array}$ & $\begin{array}{l}11.40 \\
23.5\end{array}$ \\
\hline Starch ... & ... & $\ldots$ & ... & $54 \cdot 1$ & 54.8 \\
\hline Oil & ... & ... & ... & $2 \cdot 7$ & $2 \cdot 0$ \\
\hline Fibre & $\ldots$ & $\cdots$ & $\ldots$ & $5 \cdot 8$ & $4: 2$ \\
\hline Ash & ... & $\ldots$ & $\ldots$ & $4 \cdot 4$ & $3 \cdot \$$ \\
\hline
\end{tabular}

It is usually sown with the millets, jovar and bajra, chiefly the former, with maize or cotton, or mixed with other pulses. It is not suited to the light sandy soil in which moth flourishes. It is grown in sailáb lands, but not to the same extent as mási. Muing is the pulse of the Pothwar tract in the Rawalpindi and Jhelum districts. In Rawalpindi it is as a rule somn mixed with bájra. Heavy rain in September, when it is in flower, is exccedingly harmful, and both másh and míng "suffer from the attacks of grasshoppers (tidda) when young and later on eaterpillars attack the pods and grains" (Steedman, Settlement Report of Jhang, page 93).

The broken straw and stalks are good fodder for cattle, but, as already noticed, not so good as the bhrisa of mash and moth.

40. Phaseolus aconitifolius : natural order, Loguminosc. - For botanical description see Food and Garden Moth, synonym mothi. Crops, part I, page 41, and plate XI.

The chemical composition of the grain is-

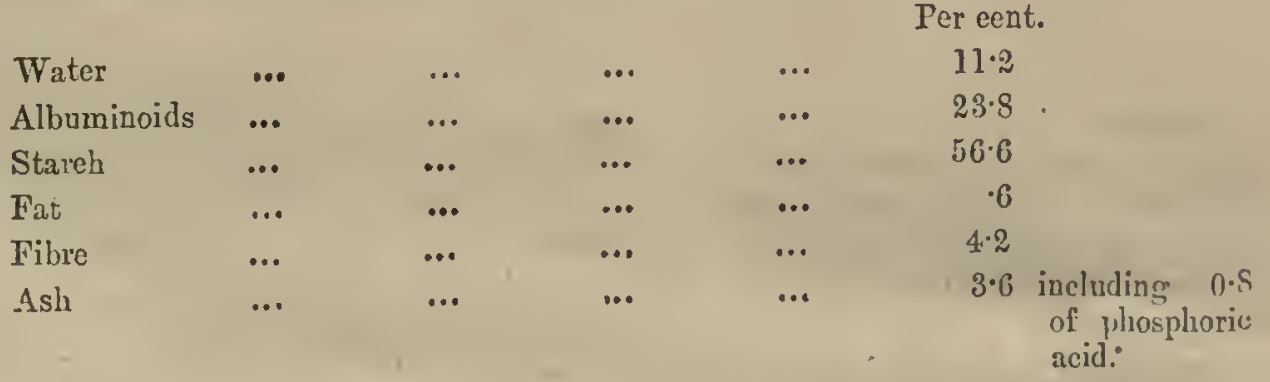

According to Purser (Montgomery Settlement Report, page 116) there are three, kinds-" bagga, jhijru, and garára. The first grows up straight; the 
leaves are not indented; it throws out no runners; and the grain is white. The other two kinds throw out runners; the leaves of $j$ hijr $u$ are indented; those of garára are not. The grain of jhijru is white with black spots ; of garara black with white spots." Jhijru is evidently the typical phaseolus aconitifolius, which derives its specific name from the fact that its leaves are deeply cut, like those of the aconite plant. Moth is a crop of the uplands and is not common in riverain tracts. It grows well in very sandy land, and the most typical association is bajira and moth, but it is also mixed with chari. In Gurgaon a variety called gora moth is the pulse usually mixed with cotton, as it spreads and does not climb. Moth is also sown alone or mixed with múng. In the low lills of the Rawalpindi district it is grown on sloping stony rakar soil. Like másh and muing it suffers from heavy autumnal rains.

The prejudices against the use of moth as a food for men which exist in the United Provinces do not appear to extend to the Punjab. In fact in Ferozepore khichri or porridge of moth and bajjra is a common dish for the evening meal, and moth, bíjr $a$ and jovo's form in the cold weather the staple foods of the people. But generally its grain is less esteemed than that of maish or ming, and much more of it is given to live stock and more especially to horses, than is spared from the two other pulses. The main use of moth is as a fodder crop, and as that it is held in high esteem. Cut green, when the seed is still unripe (gharar in Jullundur) it is an excellent food for horses, and the grain is given to them as a substitute for gram. "Boiled and mixed with crude sugar it is considered unsurpassed for getting horses and bullocks at the end of the cold weather into what natives look upon as good condition" (Purser, quoted on page 160 of Jullundur Gazetteer). In Lahore some is sown early in the hot weather at the same time as the harrú jowár and sometimes mixed with it. This is known as babuil moth (Lahore Gazetteer, page 163). The bhísa of moth is a first class fodder for cattle, the leares and the broken pods and stalks being all valuable. In Hissar the straw is given to camels, and in Attock they are given green moth. and moth.

Moth is in the Punjab the most important of the group másh, ming,

In 1910-11 the areas sown were- -

$\begin{array}{lllllll}\text { Mroth } & \ldots & \ldots & \ldots & \ldots & \ldots & \text { Acres. } \\ \text { Mruing } & \ldots & \ldots & \ldots & \ldots & \ldots & 399,621 \\ \text { Mlásth } & \ldots & \ldots & \ldots & \ldots & \ldots & 259,642\end{array}$

In making the calculation the areas in Rohtak and Gurgaon recorded under the single heading of "ming and músh" have been divided equally between the two crops.

41. Dolichos biflorus : natural order, Leguminosre.-For botanical desKulath, synonyms ranng (Iloshiarpar), Kulthi. cription see Food and Garden Crops, part III, page 2, and plate LXXXI.

Chemical analysis of unhusked grain--

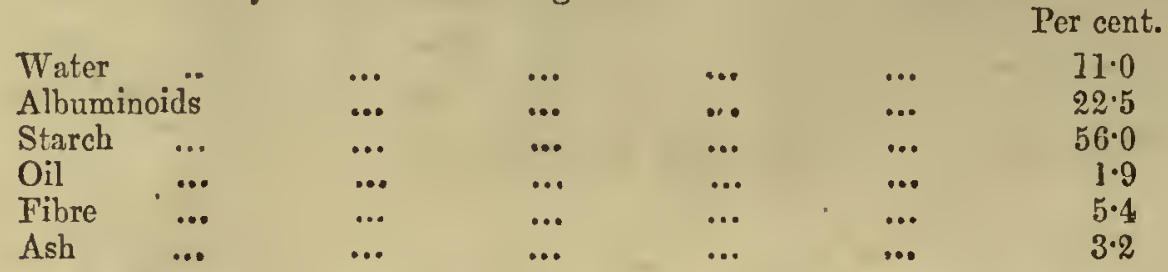

This pulse is grown on poor sloping stony soils in the lower hills and up to 6,000 or 7,000 feet. The grain is said to be hard and indigestible. In the Murree Kahuta Assessment Report Mr. Kitchin noted that "though much eaten by the poorest, (it) is eaten by no one who can get any better food." It is stated in Fuller and Duthie's, Food and Garden Crops that "the plant whereever grown is highly valued as a fodder for cattle, and in some parts of the Punjab it is sown in the spring solely for fodder."

In kharif 1910 kulath was sown in 618 acres in the Simla and 3,846 acres in the Hoshiarpur district. In RawaIpindi and Kangra it is not shown 
separately, but with "other kharif pulses." It probably occupied a very large part of the areas of 26,123 and 3,603 acres returned under that head in Kangra and Rawalpindi respectively.

42. Vigna catiang: natural order, Leguminosa.-For botanical Ramán, synonyms arwán, lobia, chзula, rangan description see Food and Garden Crops,
(Simla). part II, page 12, and plates XXIX and $\mathrm{XXX}$.

The chemical composition of the unhusked grain is -

\begin{tabular}{|c|c|c|c|c|c|}
\hline & Per cent. \\
\hline Water & & & & & \\
\hline Albumi & hoids & $\ldots$ & ... & ... & 23.1 \\
\hline Starch & $\ldots$ & $\ldots$ & $\ldots$ & .... & $55 \cdot 3$ \\
\hline Oil & ... & $\ldots$ & $\ldots$ & ... & 1.1 \\
\hline Fibre & $\ldots$ & $\ldots$ & ... & ... & $4 \cdot 2$ \\
\hline Ash & $\ldots$ & $\ldots$ & $\ldots$ & ... & 36 \\
\hline
\end{tabular}

This agrees pretty closely with that of másh and múng, but Fuller and Duthie state that the grain is less valued than that of these two pulses, as it is difficult to digest.

It is grown in small quantities in different parts of the Punjab, and more largely in the extreme south-east and in the south-west of the province. In Gurgaon it is known as chaula, and is said to be the chief kliarif crop on very inferior soils. The area sown there in kharif 1910 was 35,441 acres. The leaves and stalks are used as fodder. In Multan in 1910-11 the area sown was 9,163 acres, of which 7,346 were returned in the rabi crop statement. Mr. Maclagan noted that in Multan it is generally a catch crop after the rabi. In his Settlement Report of Montgonery, page 120, Mr. Purser stated that "vawain is grown in the spring only for fodder. It is given to cattle green, mixed with turi . . . . Cattle are sometimes turned into rawán fields to graze." In the Simla district the grain is eaten as dal or mixed with rice as khichri (porridge), while the straw is fed to eattle.

The handsome wild pea, Vigna vexillata, which is common in the low hills of the Punjab, is a near relation of rawán. It is noted on page 420 of volume III of the Dictionary of Economic Products that cattle eat it in Chutia Nagpur.

Rabi palses.

$$
\text { 43. The rabi pulses are divided }
$$

(a) the Vetches belonging to the sub-division Vicicæ of the natural order Leguminosæ-

gram, masar, churál, matar,

(b) the Clovers or trefoils belonging to the sub-division Trifolicx of the same natural ordersenji, methra, maina, shaftál, lucerne.

The latter are fodder crops pure and simple, and are fed green to cattle.

44. Cicer arietinum : natural order, Leguminosa.-For botanical

Chlola, sy nonyms chana. description see Food and Fodder Crops, part I, page 33, and plate VIII.

The chemical composition of the husked grain is-

Per cent.

\begin{tabular}{|c|c|c|c|c|c|}
\hline \multirow{2}{*}{\multicolumn{2}{|c|}{$\begin{array}{l}\text { Water ... } \\
\text { Albuminoids }\end{array}$}} & ... & & $\cdots$ & $11 \cdot 5$ \\
\hline & & $\ldots$ & $\ldots$ & ... & 21.7 \\
\hline Starch & $\ldots$ & $\cdots$ & $\cdots$ & $\ldots$ & 590 \\
\hline $\begin{array}{l}\text { Oil } \\
\text { Fibre }\end{array}$ & ... & $\cdots$ & $\cdots$ & $\cdots$ & $4 \cdot 2$ \\
\hline $\begin{array}{l}\text { Fibre } \\
\text { Ash }\end{array}$ & $\cdots$ & $\cdots$ & $\cdots$ & $\cdots$ & $\begin{array}{l}1 \cdot 0 \\
2 \cdot 6 \text {, including } 1 \cdot 1 \text { of }\end{array}$ \\
\hline Ash & ... & $\ldots$ & ... & $\cdots$ & 2.6 , including \\
\hline
\end{tabular}

After wheat gram covers by far the largest area of any crop in the Punjab, and is inportant everywhere except in hilly and submontane distriets and in a few districts in the Rawalpindi division to the north of the Salt 
Range. In tho eis-Sutlej districts it covers an enormous area. The acreage sown in the rabi of 1911 was by divisions-

\begin{tabular}{|c|c|c|c|c|}
\hline & & & & Acres. \\
\hline Delhi & $\ldots$ & $\ldots$ & $\ldots$ & $1,960,438$ \\
\hline Jullundur & $\ldots$ & ... & $\ldots$ & $\begin{array}{r}1,203,864, \text { including } 710,966 \\
\text { in Ferozepore. }\end{array}$ \\
\hline Lahore & $\ldots$ & ... & ... & 617,038 \\
\hline Rawalpindi & $\ldots$ & $\ldots$ & $\ldots$ & 354,068 \\
\hline Multan & $\ldots$ & $\ldots$ & .. & 358,636 \\
\hline & & Total & $\ldots$ & $\overline{4,494,044}$ \\
\hline
\end{tabular}

This was 26 per cent. of the rabi area and 16 per cent. of the area of both harvests.

Gram grows in all kinds of soil from stiff clay to light sand. In sandy soil it has a more feathery habit and the leaves are of a lighter colour than when growing in a clayey soil. The yield of gram is said to be greater when the soil is stiff (Field and Garden Crops, page 34). In medium or light soils it is very often sown mixed with wheat (gochni) or barley (jauchana, bejhár, or berra). The discovery that it can be grown with a fair prospect of success in very light sandy soils has led to a considerable extension of rabi cultivation in some of the western districts. The cultivation is very rough, and in heavy soils one sees gram growing among the clods of a field which has been ploughed once and in which no attempt has been made to pulverise the soil or. root out the coarse $d a b$ grass.

A good proverb on the subject is quoted on page 100 of the Ferozepore Gazetteer, edition of 1888-89, page 100 -

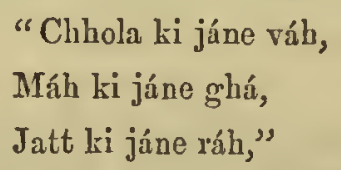

which means that gram needs little ploughing, mash does without wecling, and a Jat can travel without roads. If the land contains sufficient moisture when it is sown it requires little rain afterwards. But it is a delicate crop in some ways, and when in flower, suffers much from night frosts. Cold westerly winds shrivel up the young grain. It is also said that lightning injures the crop.

We are not concerned with its great use as human food. Of all the pulses it has the least claim to be considered a fodder crop, for its grain is of much more importance as food for horses and cattle than its straw. When bulloeks in hard work get a grain ration, gram is usually selected. It is given half-ground and is usually mixed with bhisa. The grain is also given to eamels. It is stated in Field and Garden Crops, page 35, that "gram bhisa is considered a most excellent food for cattle, but is seldom given alone, being generally used to give a flavour to more unpalatable fodders." In the Punjab it is much less esteemed as fodder. Hissar and Ferozepore are the districts with the largest gram area according to the crop returns of 1910-11. It is noted on page 174 of the Hissar Gazetteer that " the straw and leaves make an inferior kind of fodder, which is given to camels." In Shahpur gram bhusa is only given to camels except in seasons of searcity, and is considered bad for horses and milch kine. In Ferozepore it is given to horned cattle, mixed with turi, but not to cows or buffaloes when they are in milk. In Attock sheep and goats, and in Jhang cows and horses, are allowed to graze on the young crop, and the outturn is probably little, if at all, injured thereby. In Ferozepore cattle are allowed to graze in irrigated ficlds of young gram, and the practice is said to improve the nltimate outturn. A wild species of Cicer, C. Soongaricum, grows in Spiti and Iahul. It is said to fatten cattle quickly (Dictionary of Economic Products, volume II, page 284). 
45. Ervum lens or lens esculenta: natural order, Leguminosae.-For Uasri, synonyms masar, mohr, mohri. botanical description see Field and Garden Crops, part II, pago 13, and. plate XXXI.

Chemical composition of unhusked grain-

\begin{tabular}{|c|c|c|c|c|c|}
\hline \multirow{3}{*}{$\begin{array}{l}\text { Water } \\
\text { Albuminoids. }\end{array}$} & \multirow{3}{*}{$\cdots$} & & \multicolumn{3}{|c|}{ Per cent. } \\
\hline & & .. & ... & $\ldots$ & $11 \cdot 7$ \\
\hline & & $\ldots$ & $\cdots$ & ... & $24^{\prime} 9^{\prime}$ \\
\hline Starch & $\ldots$ & $\cdots$ & $\ldots$ & ... & 56.0 \\
\hline Oil & $\cdots$ & $\cdots$ & $\ldots$ & $\ldots$ & $1 \cdot 5$ \\
\hline Fibre & $\cdots$ & $\ldots$ & $\ldots$ & $\ldots$ & 36 \\
\hline Ash & $\ldots$ & $\ldots$ & $\ldots$ & $\ldots$ & $\begin{array}{l}2 \cdot 3 \text {, including } 0.7 \text { of } \\
\text { phosphoric acid. }\end{array}$ \\
\hline
\end{tabular}

Husked the fibre is reduced to 1.2 per cent. and the starch increased to 58.4 per cent. As regards its value as human food Professor Church. writes- .

"It is highly nutritions, but somewhat heating; it shonld be carefully freed from the husk or coat. The meal of lentils deprived of their coat is of great richness, containing generally more albuminoid or flesh-forming matter than bean or pea-flour. The preparations advertised under the names of 'Revalenta,' 'Ervalenta,' etc., consist mainly of lentil meal mixed with flour of barley or some other cereal and common salt" (Food Grains of India, page 139.)"

We are told that the mass of pottage, for which Esau sold his birthright, was probably composed of masi $i$ flour (Dictionary of Economic Products, volume IV, page 621). Masri alone or mixed with barley is sown in poo ${ }^{* *}$ damp riverain lands or after rice in flooded lands. Its grain is used as dal for ${ }^{\circ}$ human food and the dry stalks and leaves as fodder. It is not regarded as a valuable fodder. Mr. Purser noted that some eonsidered it heating and bad for mileh kine, while others thought it good for all eattle, as being sweet (Montgomery Settlement Report, page 122).

The area recorded in the district revenue registers in 1910-11 as sown under the heads of masri and jaumasri was 225,787 acres.

46. Lathyrus sativus : natural order, Leguminosœ:-For botanieal description see Field and Garden Churál. Crops, part II, page 15, and plate: XXXII.

Chemical composition of pea一

Per cent.

\begin{tabular}{lcccccr} 
Water $\ldots$ & $\ldots$ & $\ldots$ & $\ldots$ & $\ldots$ & $10 \cdot 1$ \\
\multicolumn{2}{l}{ Albuminoids } & $\ldots$ & $\ldots$ & $\ldots$ & $\ldots$ & $31 \cdot 9$ \\
\multicolumn{2}{l}{ Starch and fibre } & $\ldots$ & $\ldots$ & $\ldots$ & $\ldots$ & $53 \cdot 9$ \\
Oil $\quad \ldots$ & $\ldots$ & $\ldots$ & $\ldots$ & $\ldots$ & $\cdot 9$ \\
Ash $\quad \ldots$ & $\ldots$ & $\ldots$ & $\ldots$ & $\ldots$ & $3 \cdot 2$
\end{tabular}

called in the United Provinces Kesari.

This humble pulse is grown in damp riverain lands and is used almost wholly for fodder, espeeially for cows and female buffaloes. The dal has a bad reputation for human food, and indulgence in it is undoubtedly sometimes. followed by paralysis of the lower limbs. The eurious statement in the late Mr. O'Brien's Settlement Report of Muzaffargarh that "to sleep in a pea field is believed to produce a kind of paralysis called munda," probably refers to churál. Mr. Purser in the Settlement Report of Montgomery, page 122, writes:- "This crop is grown ehiefly for green fodder. The plants are pulled up or cut. The dry stalk and leaves are eonsidered good fodder for cattle, but not for horses," as causing constipation. Mr. Maclagan on page 220 of the Multan Gazetteer puts the average selling value of churál at Ris. 10 per acre. 
47. Pisum arvense: natural order, Leguminosa.-For botanical descripMatar. tion see Field and Garden Crops, page 17, and plate XXXII B.

Like churál this pulse is mostly grown in moist river lands and used for foddor. The peas have no poisonous qualities, and on page 90 of the Jhang Settlement Report the late Mr. Steedman noted that the pods were picked green and eaten as a vegetable, and that the grain was not usually threshed except for seed.

In the south-western districts peas (churál and matar, which are not distinguished in the crop returns) are important fodder crops. The area in Multan in rabi 1911 was 40,856 acres.

The area recorded under churál and matar or peas in the district revenue registers was 148,971 acres. Few districts outside the Multan division sow any large acreage.

48. Melilotus parviflora : natural order, Leguminosa.-For botanical Senji. description see Hooker, Flora of British India, volume II, page 89 . It has minute yellow flowers growing in a raceme (see illustration I). It does not appear to be cultivated to any extent in the United Provinces, for it is not mentioned in Fuller and Duthie's Field and Garden Crops, but in the Punjab it is an important fodder crop. It is often grown in irrigated land after cotton or maize, being sown between the lines while these erops are still standing. Farmers sow it to supply green fodder to their own cattle and do not as a rule well it, except near cities like Lahore and Amritsar, where it fetches a good price. doubtless cat.

Its relation melilotus alba is a Punjab wild plant, which cattle

49. Trigonella fanum-gracum : natural order, Leguminosa-For boMethra, synonyms metha, methi, methun. tanical description see Ficld and Garden Crops, part III, page 46 , and plate XCIX, also Hooker Flora of British India, volume II, page 87. It has some resemblance to senji, but is distinguished by its humbler growth and larger light yellow flowers. It is fairly common in damp riverain lands, but is also grown on irrigated lands, where it is often sown between the lines of cotton. It is used as green fodder, and can be cut several times if the plant is watered after each cutting.

50. Medicago denticulata (sce illustration I).-Is a common Punjab Maina. wild plant, which no doubt is eaten by cattle, though it is not included in the list of fodder plants in the Dictionary of Economic Products. It springs up thickly in Gujranwala in cotton fields, and is watered, so may there be considered a fodder crop. A very considerable part of the area of 624,020 acres shown under rabi fodder in statement II was no doubt under senji and methra.

51. Medicago sativa : natural order, Leguminose.-It is perhaps a cultiLucerne. vated variety of medicago falcata which grows wild in Kashmir and Kunawar (sce Hooker, Flora of British India, volume II, page 90). The flowers are usually purple. The plant has been introduced as a crop from Europe, and is commonly grown at remount depôts, to supply green fodder for horses. It covers a large area at the Mona Remount Depôt in the Gujrat district. It belongs to the same group as methra, senji, maina and shaftál (see also Fuller and Duthie's Food and Garden Crops, part III, page 61). The medicagos are distinguished by their curious spirally twisted pods. There are three wild species besides M. denticulata mentioned above in the plains-M. lupulina, M. lociniata, M. minima - no doubt all useful to cattle though not included in the list of fodder plants in the Dictionary of Economic Products.

52. Trifolium repens : nalural order, Leguminosa.-It is cultivated in Shaftál. Afghanistan, Hazara, Peshawar, and Bannu, and in the Attock tahsil of the Attock district. In Bannu it is, like senji and methra, usually sown in maize 


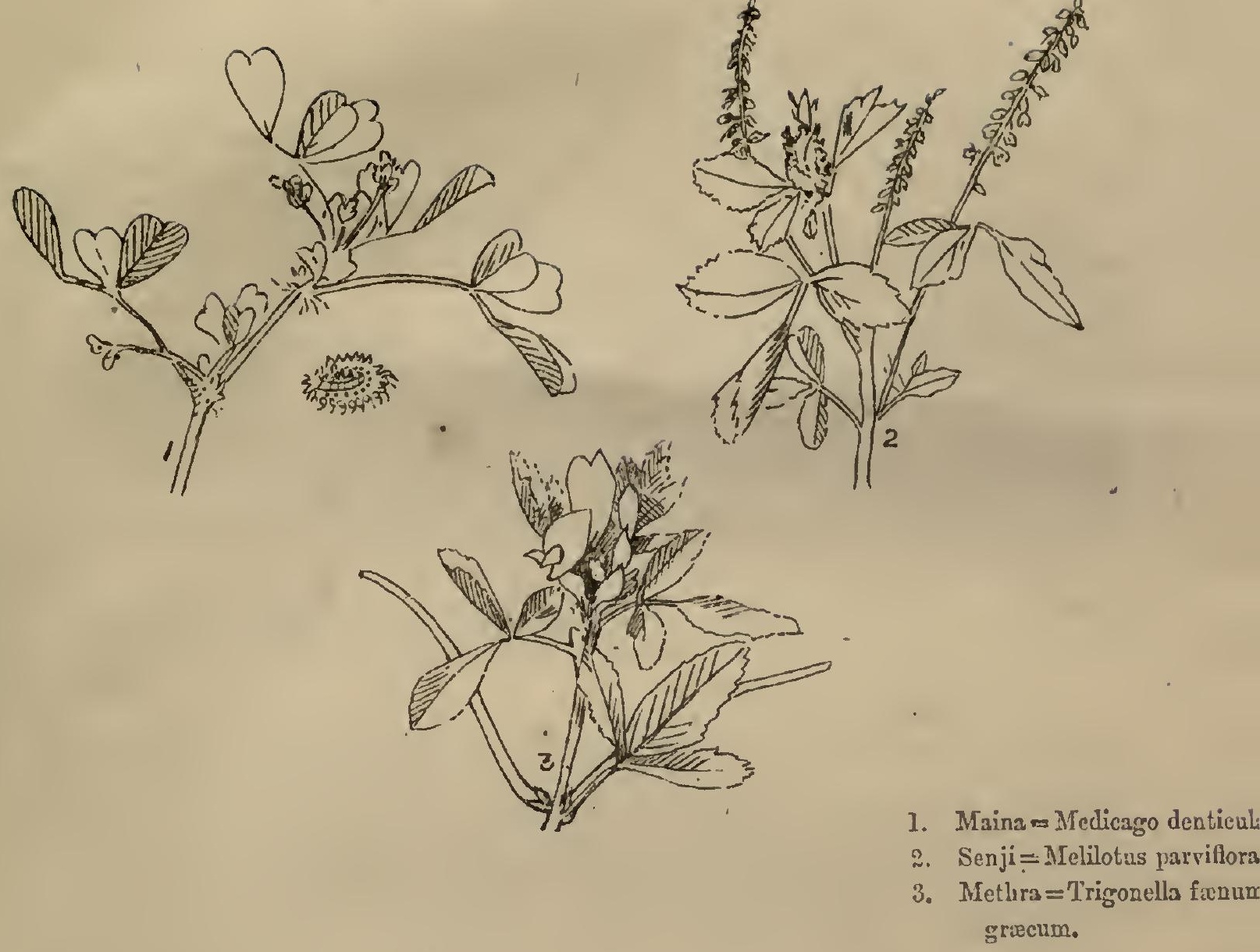



and cotton fields. It belongs to the same group as methra, senji, and Iucerne; and it might be worth while to try to extend its cultivation in the Punjab. Trifolium pratense (red), Trifolium repens (white), and Trifolium fragiferum (straw-berry headed trefoil) are English elovers, which also grow wild in the hills.

53. $\Lambda$ foreign leguminous plant, Arachis hypogrea or the ground-nut The ground-nut or múngphsli.

(see figure 22 in Church's "Food Grains. of India ") is now much cultivated in Southern India. It has the curious property of burying its pods in the ground. "The secds are a valuable source of oil, and are also eaten. The leaves and branches of the plant are....... an excellent fodder. The hay is rery nutritious, much increasing the milk of cows. The cake holds a high reputation as a food upon which cattle rapidly fatten." (Dictionary of Economic Products, volume I, page 287). Probably the Punjab climate is too cold for the groundnut.

54. Glycine hispida : natural order, Leguminosa.-For botanical des: Bhut. cription see Field and Garden Crops, part III, page 3, and plate LXXXV.

This is the soy bean of China and Japan of which the seed is now largely exported to England for oil. In the United Provinces it is cultivated under the name of bhat in the lower hills and in a few of the neighbouring plain districts. "The plant affords excellent fodder for all kinds of stock, if harrested before it is fully matured." The extent to which it is now cultivated in the Punjab hills requires investigation. It appears from page 243 of Punjab Products that several samples of a plant called bhut, which was identified as soja or glycine hispida, were sent to the Lahore Exhibition of 1864 from the Hill States. This was probably an inferior rariety of the Chinese plant. The desirability of introducing into the hills and submontane districts a good lind of soy bean may be judged from the following extracts from the Dictionary of Economic Products, rolume III, page 111:-

"The chemical composition of the bean, according to Professor Kinch, places it above. all other pulses as an albuminous food, while that of the straw also surpasses in nitrogenous value that of wheat, lentils, and even hay. The following composition is given by ProfessorChurch :- In 100 parts of the bean water 11, albuminoids $35 \cdot 3$, starch and sugar 26, fat 18.9, fibre $4: 2$, ash $46 \ldots . . .$. . The soy bean is an extremely valuable fodder plant. If cut just when the pods are, fully formed, it makes most nutritious bay, and the residual cake (after oil has been expressed from the seed), which contains, according to Church, 40 per cent. of flesh-form. ing materials and 7 per cent. of oil, is an extremely rich cattle food."

\section{CHAPTER IV.-Orlseeds, Turnips and Carrots.}

55. We now come to a group of plants of great importance in the fecding of cattle because the roots and the green leares and stalks are eaten, Crops incladed in chapter. and the refuse made after oil has been expressed from the seeds is the clicf source of oil-cake. These plants belong to the order Cruciferæ, and threc-fourths of them, sarson, toria and turnips, are varieties of Brassica campestris. Taramira. belongs to the nearly related genus Eruca. Although carrots belong to a different natural order, it is convenient to include them in this section, as their useas fodder is similar to that made of turnips.

56. Brassica campestris ; sub-species napus, varieties glanca, trilocularis; sarson, вynonyms saron, siraan, sarbhnt, malwáni. quadrivalvis, and dichotoma. - Forof Field and Garden Crops and plates XXXVII to XL.

Natives recognise two varieties, black and yellow. The former, which is: Brassica campestris, variety dichotoma, is said to be more hardy, but less rich. in oil. 
Sarson is somn either alone, or mixed with wheat, barley, gram, or other crops. When mixed it is sown either seattered or in lines $(a d)$. It is one of the erops sown for fodder in cotton fields, while the cotton is still standing. Except in the south-western districts, where it is unimportant, it is rarely irrigated. It is noted on page 168 of the Lahore Gazetteer, edition of 1893-94, that on well lands it " is seldom sown except with wheat, when the two are intended to be cut together for fodder." It is a delicate plant, very liable to injury from frost. It ripens the earliest of the rabi crops exeept toria.

The seed yields a bitter oil (karwa tel), which is good for burning and also for cooking, though for this purpose not equal to til. The refuse, after the oil has been expressed, is a raluable oil-cake, but much of the seed is exported to Europe. The young flowering shoot is used for ság. Sarson, when sown as a mixed crop, is pulled up and fed green to cattle in January and February. It is noted on page 123 of Purser's Montgomery Settlement Report that when well imignted and manured two cuttings for fodder can he got, if the first is taken before, or very carly in Magh. The dried threshed straw is of no use.

The area under sarson in 1910-11 was 350,000 acres, but it is extremely difficult to record the area of this crop accurately, and in one or two districts it is lumped with taramina or toria. The districts with the largest areas in rabi 1910 were-

\section{Acres.}

$\begin{array}{llllll}\text { Ferozepore } & \ldots & \ldots & \ldots & \ldots & 80,641 \\ \text { Karnal } \ldots & \ldots & \ldots & \ldots & \ldots & 47,698\end{array}$

It is a farourite crop in Gurgaon, Karnal and Ludhiana. In the Rawalpindi and Multan divisions táramíra is much more important than sarson.

57. Brassica campestris; sub-speeies napus, variety toria : natural order Toria, aynonyms satlri, tirpakhi.

Crucifera.-For botanical description. see pages 29-30 of Field and Garden Crops and plate XLA.

In Sialkot toria is a crop of some importance, and it was probably intro. duced into the Lower Chenab and Lower Jhelum Canal Colonies by immigrants from that district. It has hecome a very popular canal-irrigated crop in both colonies, on the Upper Bari Doab Canal in Lahore and on the Sidhnai Canal in Multan.

The following passage from the Gazetteer of the Lower Chenab Colony
may be quoted:-
"The popularity of toria with the colonists is easily explicable. It is in the ground
for only some $3 \frac{1}{2}$ months, requires but little water, and that mainly at a time when wheat
sowings lave not commencel. Once sown it makes no demands on the energies of the
colonists. . . There is a uniformly steady demand in the market for the seed, which is
exported mainly to Italy and Marseilles, to be manufactured into "finest Lucea oil '. . . .
It is curious that the zamindar will not eat the oil, which he uses himself only as an illumin-
ant. It is popularly considered to be heating. A little toria is grown by the Janglis
as green fodder for cattle and by Biloches for their camels . . . The pressed seed is
given to buffaloes to increase lactation."

In Sialkot toria is gencrally an irrigated crop, but in Karnal it is mostly grown without irrigation. The chahi area, however, expands in a year of drought when the people want a crop which ripens quickly. The name sathri, by which it is known in some western distriets, is an allusion to the fact that it is supposed to ripen (or perhaps to be of use for fodder) in sixty dars. It is a delicate crop, but ripens so early that it stands a good chance of escaping damage from frost. It is mainly grown for the export of the seed, which fetches a good price. The oil-cake is not liked by cattle as it has a bitter taste. As fodder toric is much less appreciated than sarson, as the leaves are said to be bitter. But on pare 221 of the Multan Gazctteer, edition of 1901-02, Mr. Maclagin noted that in that district outside the Sidhnai area " it is mainly grown along with turnips, and forms, when so grown, a green fodder, which is available for the eattle carlier than the turnips.". 
Owing to its popularity in the new eanal colonies toria now covers a larger area than sarson. The area given in statement II is 440,701 acres.

In rabi 1910-11 the area sown with toria was returned as 192,140 acres in Lyallpur, 81,472 acres in Shahpur, 59,221 acres in Lalore, and 24,378 acres in Amritsar.

The area for the whole province was probably about 400,000 acres.

Other sources of oil-cake.

58. It may be as well to note here the other sources of oil-cake.

The chief is til (Sesamum indicum : natural order, Pedalinea), which is specially valued for use in the cold weather.

Alsi (Linum usitatissimum : natural order, Linacece) is another source.

Gonglu, synonyms shalgqu, ság, gandraf.

59. Brassica campestris ; subspecies napus. - The chemical composition of the root is -

\begin{tabular}{lccccc} 
& & & & \multicolumn{2}{c}{ Per cent. } \\
Water $\ldots$ & $\ldots$ & $\ldots$ & $\ldots$ & $\ldots$ & $90 \cdot 4$ \\
Albuminoids & $\ldots$ & $\ldots$ & $\ldots$ & $\ldots$ & $1 \cdot 0$ \\
Fatty and beating matters & $\ldots$ & $\ldots$ & $\ldots$ & $7 \cdot 9$ \\
Inorganic matters & $\ldots$ & $\ldots$ & $\ldots$ & $\ldots$ & 0.7
\end{tabular}

The importance of turnips as food for cattle in the districts of the Multan division is rery great. They are also largely grown in Shahpur, Lahore, Gujranwala, Mianwali, and Gujrat. On page 222 of the Multan Gazetteer Mr. Maclagan wrote :--

"The Multan district grows more turnips than any distriet in the Punjab. This erop represents 6.3 per cent. of the cultivation, and its function is to keep the cattle alive when the jowar fodder is finished, until the wheat and wheat straw are available. It is used to a small extent as food, the stalks (gandal) being cooked and the roots being eaten either raw or cooked, but it is not cultivated with this object. There are two varieties, the red and the white, of which the white are said to be the better and the more widely cultivated. The crop needs a fair amount of water and is rarely found outside the reach of well irrigation...... The ploughings begin in July and the seed is sown shortly after. The erup receives six or seven watcrings during the autumn and winter; it is manured if possible, and sometime weeded. The roots are not taken up at one time and stacked, but are pulled from time to time from the end of November onwards, and given at once to the cattle. As a rule the tops and roots are given together, but sometimes the tops are cut and fed off separately, while the roots remain in the ground. The plants are never thinned or transplanted. The erop is sometimes grown along with other creps such as methra, gram, sathri and ussun."

With this may be compared the late Mr. Steedman's account of tho crop on page 89 of his Settlement Report of Jhang :-

"Turnips are on well lands a most important crop in this district. The well oxen are very heavily worked during the wheat sowings and the first waterings, and require a large amount of strengthening food. This is furuished by the jowar and turnip crops. There is nothing else. If the turuips fail, or are late as they often are, owing to the failure of the first sowings, the working power of the bullocks is materially weakened, and the area under wheat does not get properly watered. 'Turuips, raw and cooked, are also eaten largely by the tenants during the cold weather. To them, no less than to the bulloeks, a bad turnip crop is a serions misfortune.

"The best land on the well, well ploughed and liberally manured, is allotted to this crop. The land will gencrally have been plonghed up after rain once before the seed timc arrives. The land is then irrigated and ploughed from three to six times with one or two rollings in between, if there are any clods to be broken up. The seed is sown broadcast, mixed with sand or earth or manure. Then the soil is once more rolled, and the irrigation beds and chaunels are made. If the soil has now beeome somewhat dry, a watering is giren at once, but usually the first watering is given a few days after the plants have come up. When turnips are sown on well lands in soil that has been plonghed up once or twice previously a couple of plouglings are given, and then the well beds and irrigation channels are banlied up. 
"For sailab lands the proeess is different. The land is plonghed twice or three times. and rolled. The seed is sown broalcast and plonghed in with very shallow furrows. * * *

"The crop ripens in three months. Zamindars say turnips are not ready till the first frosts. It is watered five or six times. No weedings or hoeings are given. $\Lambda$ tarnip crop should not be too thick, or it runs to leaf, and the bulbs suffer. A first class crop is that which yields a good fodder crop of leaves first, and a heavy root crop afterwards.

"The turnip leaves are cut once, sometimes tivice on the very best lands, and then the bulbs are pulled up. On sailab land the leaves are not cut, but the whole plant is pulled up. The bulbs grow very larce on sailab lands. I have also seen them eaten on the ground, but this is of course very different from what is meant by the process at home. The great difficulty about the turnip crop is to sow the seeds early and jet to get it to germinate well."

In crop returns turnips and carrots are clubbed together, but in districts where turnips are important carrots form an insignificant part of the total. In rabi 1911, the districts returning the largest acreage were-

$\begin{array}{llllll}\text { Multan } & \ldots & \ldots & \ldots & \ldots & 59,426 \\ \text { Montgomery } & \ldots & \ldots & \ldots & \ldots & 43,210 \\ \text { Shahpur } & \ldots & \ldots & \ldots & \ldots & 41,707 \\ \text { Gujranrvala } & \ldots & \ldots & \ldots & \ldots & 23,698 \\ \text { Muzaffargarh } & \ldots & \ldots & \ldots & \ldots & 22,791 \\ \text { Lahore } & \ldots & \ldots & \ldots & \ldots & 14,990 \\ \text { Gujrat } & \ldots & \ldots & \ldots & \ldots & 10,584\end{array}$

The total acreage given in statement II is 280,652 acres.

60. Brassica juncea : natural order, Cricifere.-For botanical deseripAhur, synonyms arhu, arhion. tion of the mustard plant see Field and Fodder Crops, page 33, and plate XLI.

Mustard is not much grown in the Punjab. It is stated on page 31 of the Field and Garden Crops that in the United Provinces "it is not uncommonly cut green in January and February and given to cattle, should the supply of cattle fodder have run short."

61. Eruca sativa : natural order, Crucifere.-For botanical description see Field and Garden Crops, page 26,

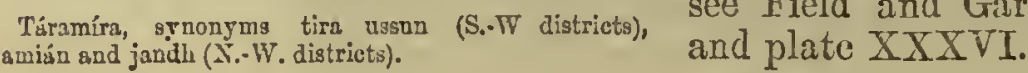

Tramira is the oil-seed par exeellence of the districts of the Rawalpindi division lying to the north of the Salt Range and of Mianwali. It is there an unirrigated erop. The description given in the Attock Gazetteer (page 152), which would also apply to Jhelum, Gujrat, Rawalpindi and Mianwali, may be quoted :-

"Táramira is one of the three important rabi crops, and in Fattehjang and the Attock Nala ranks after wheat alone. It needs no cultivation, the seed is cheap, and the crop will grow on any land. It is grown almost exclusively on the most inferior kinds of unirrigated land, much of the poorest rakar being able to produce nothing more than a light táramira crop, unless it be a very poor cotton. Táramira is sown along the edges of paths, over the ridges between fields, is dribbled in among the bajra, and is scattered broadcast about the fields whenever rain falls in November. The seed is cheap, and the zanindar who cannot afford wheat seed can always afford táramíra. If the crop fails there is little loss, and if it succeeds the profit is large. It is a most useful crop. Like gram it is used as a vegetable when green. A good deal is also consumed for fodder. It is the favourite food of camels. Bnt the bulk of the crop is allowed to ripen, and a valuable oil extracted. The only objection to taramira is that it is an exhausting crop, and is considered the most exhansting of all rabi crops. In a good year the táramira pays the revonue of the whole year, and great quantities are exported. In Fattehjang itself thero are a great many oilpresses, and the oil stored in kerosine tins is sent into Rawalpindi and Gujar Khan for export. The oil for lighting purposes has now been snperseded by kerosine, but it is considered very strengthening and healthy as an article of food, and in many ways takes the place of $g h$ i for frying, \&c. The ontward application in plague and other cases is said to be very beneficial. The Kot estate makes a large income annually from this crop. A remarkable characterstic of táramíra is its vitality. It is often self-sown. In rears of good rainfall it springs up everywhere, even on the house tops, in the Kala Chitta Forest, and among the ballast on the 
mailway lines. The real matured area can never be determined, and the recorded area can be important crop than even gram." for cattle.

In Rawalpindi besides being cooked as a potherb it is the farourite food

In Multan, Muzaffargarh, and Dera Gliazi Khan, where it is known as Missun, it is often an irrigated crop. On page 221 of the Multan Gazetteer

"Ussun does not reqnire much moisture; it is grown on pure canal or baráni cultivation. It is often found on the outer reaches of well estates where it will get water if there turnips."

In Muzaffargarh it is sown as fodder with peas or gram, and there " in very hot weather ussun is mixed with bruised barley, and wetted and given
as a cooling food to buffaloes." were :-

The distriets which returned the largest areas as sown in rabi 1910

$\begin{array}{lcccc} & & & & \text { Acres. } \\ \text { Dera Ghazi Kban } & \ldots & \ldots & \ldots & 81,806 \\ \text { Ferozepore } & \ldots & \ldots & \ldots & 21,906 \\ \text { Attoek } & \ldots & \ldots & \ldots & 19,317 \\ \text { Multan } & \ldots & \ldots & \ldots & 14,276 \\ \text { Mianwali } & \ldots & \ldots & \ldots & 13,044 \\ \text { Jhelum } & \ldots & \ldots & \ldots & 13,699 \\ \text { Ámbala } & \ldots & \ldots & \ldots & 12,697 \\ \text { Muzaffargarh } & \ldots & \ldots & \ldots & 11,346 \\ \text { Gurgaon } & \ldots & \ldots & \ldots & 10,15 \pm\end{array}$

The figures for Dera Ghazi Khan include sarson and toria, but the deduction to be made on that account is probably not large.

The handsome violet flowered chanáka (Diplotaxis griffithii), which grows freely near the Salt Range, is worth experimenting with as a possible source of oil and fodder, especially as the seed has some small commereial ralue as a drug (Attoek Gazetteer, page 19).

62. Daucus carota : natural order, Umbelliferia.-For botanical deseripGájar (carrots). tion see Hooker's Flora of British India, rolume II, page 718, and illustration EXXVITT in Field and Garden Crops. A curious feature of the plant is that the central flower in the umbel is often red. In the Punjab it is an irrigated. crop, and generally grown in small patches on wells. The tops are fed green: to cattle in January and February. The roots, besides being a useful food for men, are given to horses.

\section{CHAPTER V.-OTHER Crops:}

63. Gossypium neglectum : natural order, IIalvacea.-For botanical Vanwár cotton, eynonyms kapáh, kapás, bári (eas. deseriptions see Field and Garden Crops, teru districts), vír, víran.

part I, page 75, and plate XVIII.

The eatton seed (binsla, varemoa, peve), which contains much oil, is a very valuable food for milch kine. In Karnal after the cotton is picked the cattle are turned into the field to eat the leaves (Karnal Gazetteer, edition of 1890, page 200).

61. Saccharum officinarum : natural order, Graminece.-For botanical Kamád, synonym ikh (eastern districts). : description see Field aud Garden Crops, part I, page 55, and plate XIV.

When eane is reaped the arrow or top (ág or pandl) is cut off and used as fodder. A bad feature of a fodder famine is the extent to which cane has to. be sacrificed to keep the cattle alive. In Gujranwala, even in a normal year, a. great deal of the cane goes to feed the bullocks. 
65. Crotalaria juncea : natural order, Leguminosæ.-For botanical de:scription see Field and Garden Crops, part I, page 82, and plate LXXXII.

Sani, şnonym san.

This leguminous plant, which is grown in small patches for its fibre, should be carefully distinguished from sankukra (also called san and sinjubára), which is Hibiscus cannabinus, natural order Malvaceœ, also grown for fibre, which is planted as a hedge round cotton and cane fields. It is stated in "Field and Garden Crops" that in the United Provinces the tops of sani are cut off and given to cattle when the plants are in full flower, and Mr. Duthie notes in his Flora of the Indo-Gangetic Plain, page 206, that the green plant as well as the seeds are sometimes given as food to milch cows.

There are several species of Crotalaria which occur as wild plants in the Punjab. The only two included : in the list of fodder plants in the Dictionary of Economic Products are Medicaginea and C. linifolia, but C. burhia is valued for fodder in Rajputana (Flora of Indo-Gangetic Plain, page 202), and it is unlikely that cattle neglect the others.

66. Lepidium sativum: natural order, Crucifera.-For botanical deHalon. scription see Hooker's Flora of British India, volume I, page 159 , and illustration II appended.

It is a very unimportant rabi crop. A few scattered plants are sometimes seen mixed with othar crops. The seeds contain a good deal of oil. Its use as fodder is not referred to in the "Ficld and Garden Crops of the United Provinces" (part III, page 49), but Purser on page 185 of the Jullundur Gazetteer mentions it as one of the spring fodder crops. It was apparently introduced into India from the West, but its relation, Lepidium draba, is a weed of cultivation in the Punjab and is one of the English wild flowers. No doubt it is one of the plants weeded out of the fields, which finds its way into the cattle trough, for it is greatly valued as greon foclder at Quetta, where it is a common weed (Dictionary of Economic Products, volume III, page 4.15, and volume IV, page 626).

67. Cichorium intybus : natural order, Compositc.-For botanical deKásni. scription see Hooker's Flora of British India, rolume III, page 391 , and plate LXXIV in Fuller and Duthie's "Food and Garden Crops."

Chickory is an English wild plant and also grows wild in the NorthWestern Himalaya. It is found apparently wild in the Punjab plains, but is there perhaps originally an escape from cultivation.

It is grown alone or mixed with sarson as a fodder crop on wells in Gurgaon and the Jhajjar talisils of Rohtak.

68. Carthamus tinctorius : natural order, Composite.-For botanical Kuoumbh, synonym kharar. description see Fuller and Duthie's Food and Garden Crops, part I, page 51, and plate XIII.

In the last twenty years the cultivation of safllower for the sake of the dye yielded by the flowers has been killed by the introduction of aniline dyes. About 1885 the area under safflower in the Hoshiarpur district exceeded 6,000 acres; in rabi 191147 acres werc sown. The area in Ambala was nearly 5,000 acres in 1887-88.

In Gujrat and Jhelum safllower is sown in lines in wheat fields like sarson, and the plants are pulled out and fed to the cattle in January and February.

The ripe seed used to be valued in the United Provinces for its oil, which was used to adulterate ' $g h i$, and the refuse made an excellent oil-cake (Field and Garden Crops, page 51). But in Gujrat only enough is allowed to fipen to provide for the next sowings. 
ILLUSTRATION II.

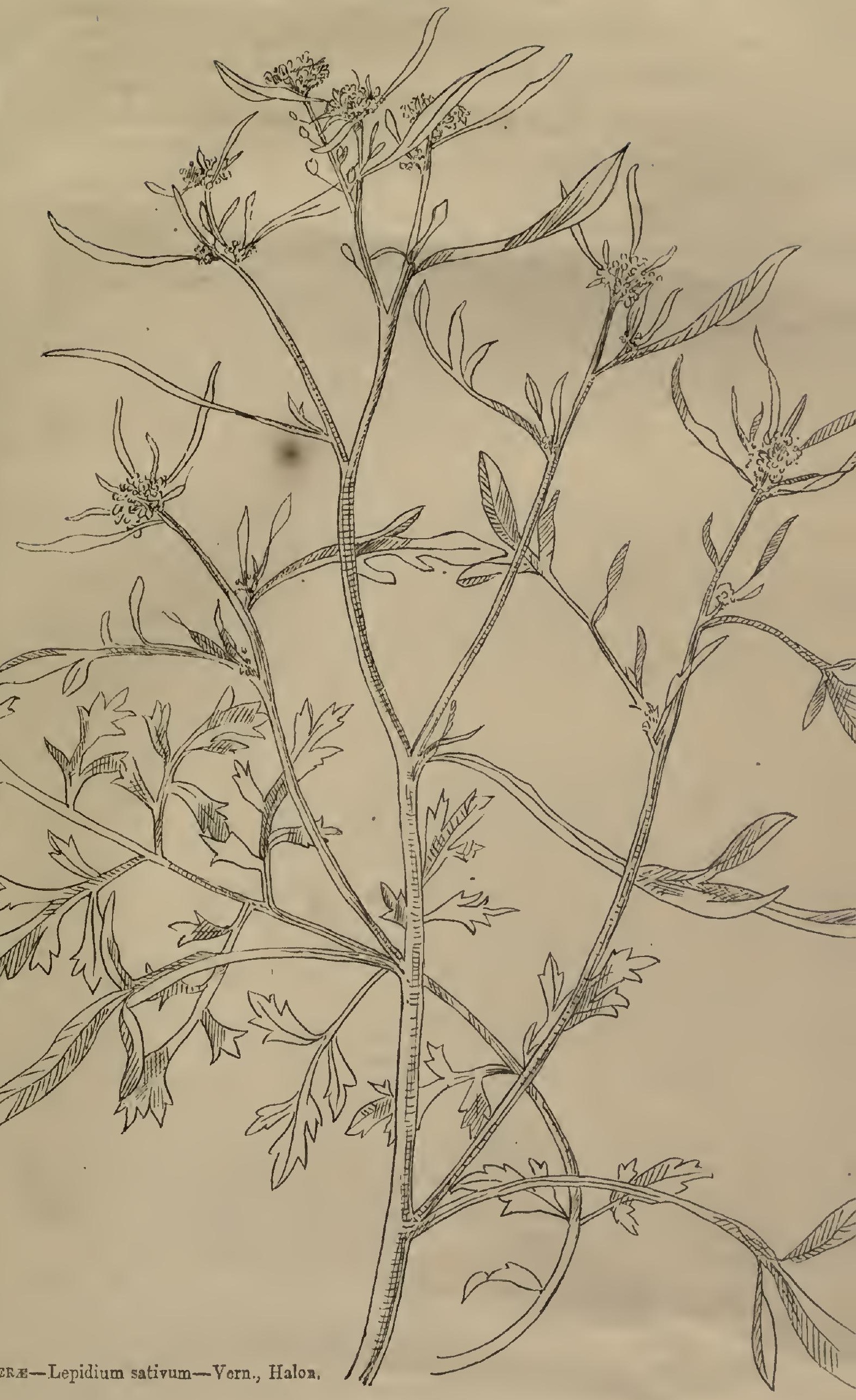




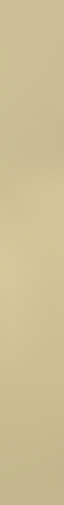

. 
Pohli (Carthamum oxyacantha), a thorny weed with yellow flowers, a near relation of saffiower, is common in the Punjab, and in the north-west of the province poor people in times of scarcity use the seeds as food. They also contain oil.

69. In the sand hills of the Thal of Mianwali, Muzaffarmarlh and Jhang Ifindrána (melons), synopym titak (smaller). melons are a catch crop. The rinds aro Kaul has given me a note on the subject :fed to eattle. Pandit Hari Kishan

"The melon is split up, the seeds separated and the pulp eaten by men, the shell being riven to the cattlc. Where melons grow in great abundance, the pulp and the shell are both thrown to the cattle, only the choicest melons being reserved for mon. The secds are dricd, parched, and caten like parched gram, or in years of scarcity pounded into flour and caten in the form of cakes. Camels are not fed on melons, partly because they are considered injurious for camels and horses, and partly bccause camels bave plenty of other foddcr. They are, however, allowed to eat the creeper, and, when grazing in melon fields, do not mind picking up as many small melons as they can."

70. Indigofera tinctoria : natural order, Leguminosce.-For botanical Nil (indigo). description see Fuller and Duthie's Field and Garden Crops, part I, page 43, and plate XII.

The cultivation of indigo for the dye and the supply of seed to the Behar planters was once important in the eastern districts, but the area under the crop there is now quite insignificant. It is noted in the Rohtak Gazetteer (page 104) that "latterly it is said to have been tested as a fodder crop." Several of the wild Indigoferas are in the list of fodder plants in volume III of the Dictionary of Economic Products, but it does not include the "káthi" or Indigofera gerardiana so common in the low hills. Indigo is still cultivated to a considerable extent in Multan, Muzaffargarh and Dera Ghazi Khan for the sake of the dye which is exported to Afghanistan, Bokhara and Yarkand (Multan Gazetteer, page 215).

71. Acknowledgments are due to the officers named in this note and to Acknowledgments.

Mr. Lall, Settlement Officer of Gujranwala, and to M. Sant Singh, President of the Kalsia Council, for their ready response to requests for information. Mr. Dunnett has kindly agreed to correct the proofs in my absence. 



\section{S T A T E M E N T S.}


STATEMENT I.-AREAS, WELLS, PlOUghs,

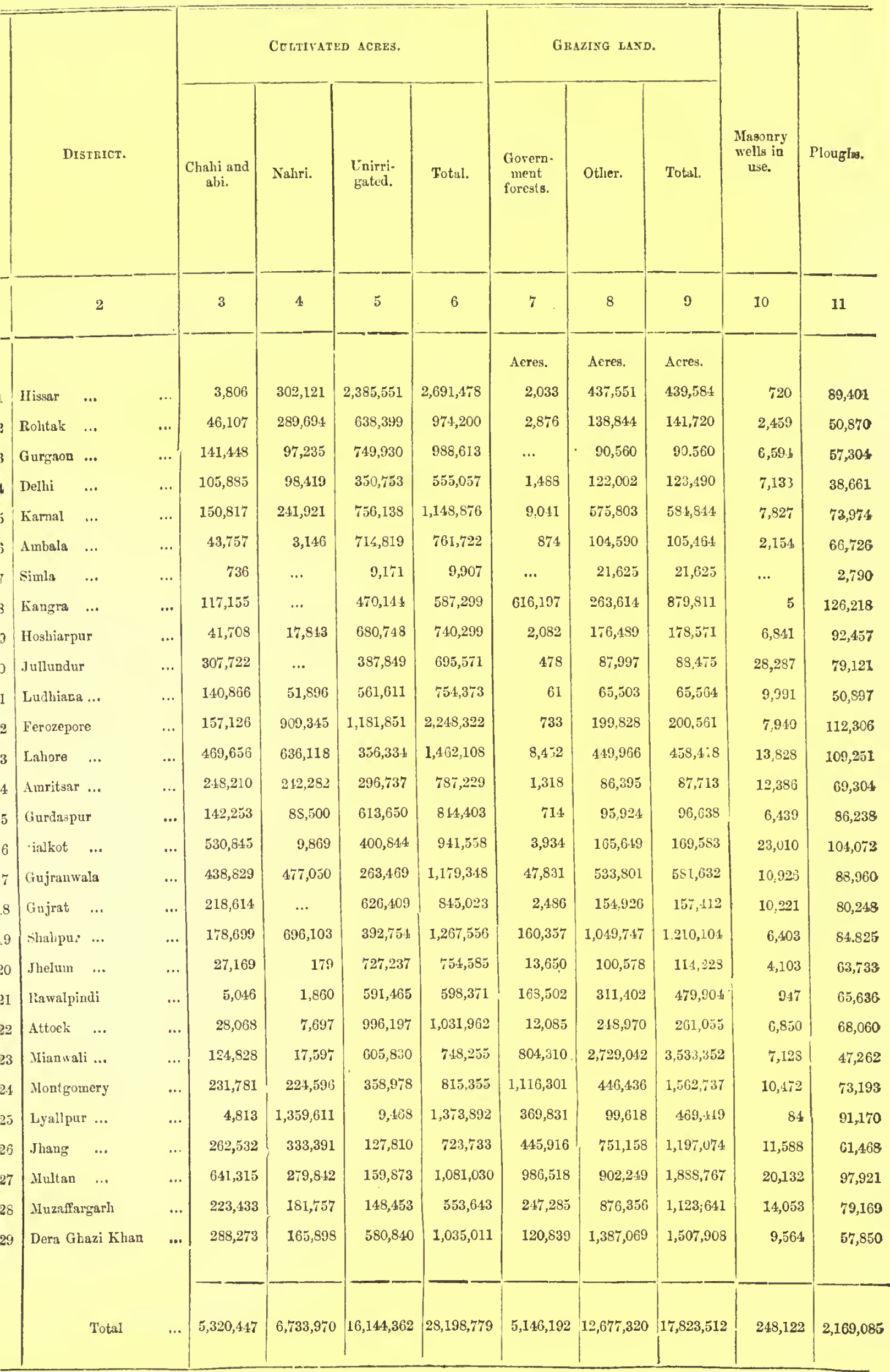


CATTLE, CARTS, AND POPULATION.

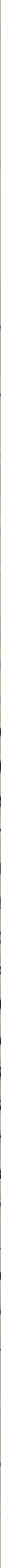


STATEMENT II.-ACRES SOWN IN

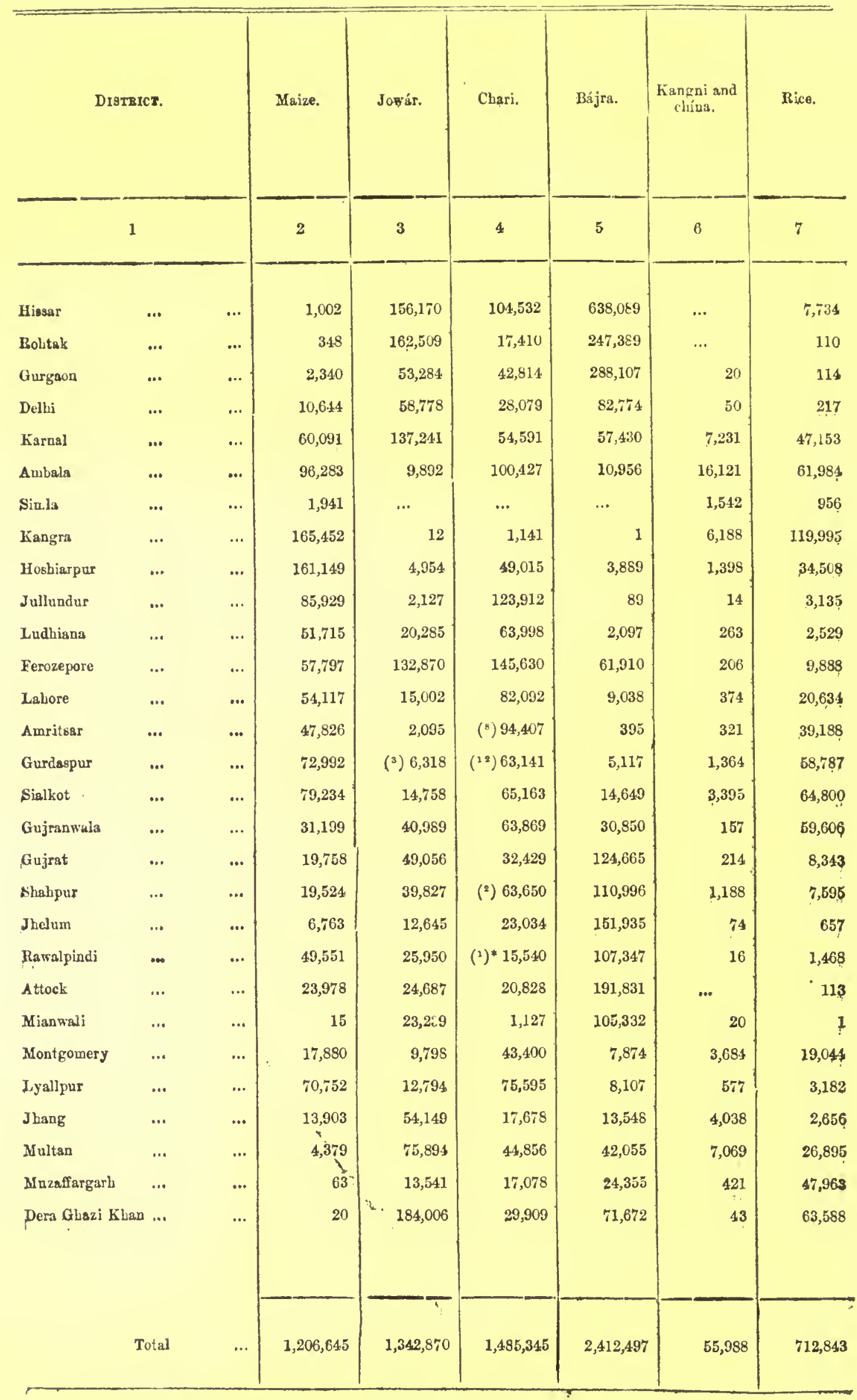

- (1) The heading in crop return is chára maveshi, so other cropo may be included.

( $\left.{ }^{2}\right)$ Of this 22,532 entered in rabi crop return.

(') Jowár and chars.

(') Includes táramtra.

(3) Eotercd as chdra. 


\section{KHARIF 1910-RABI 1911.}

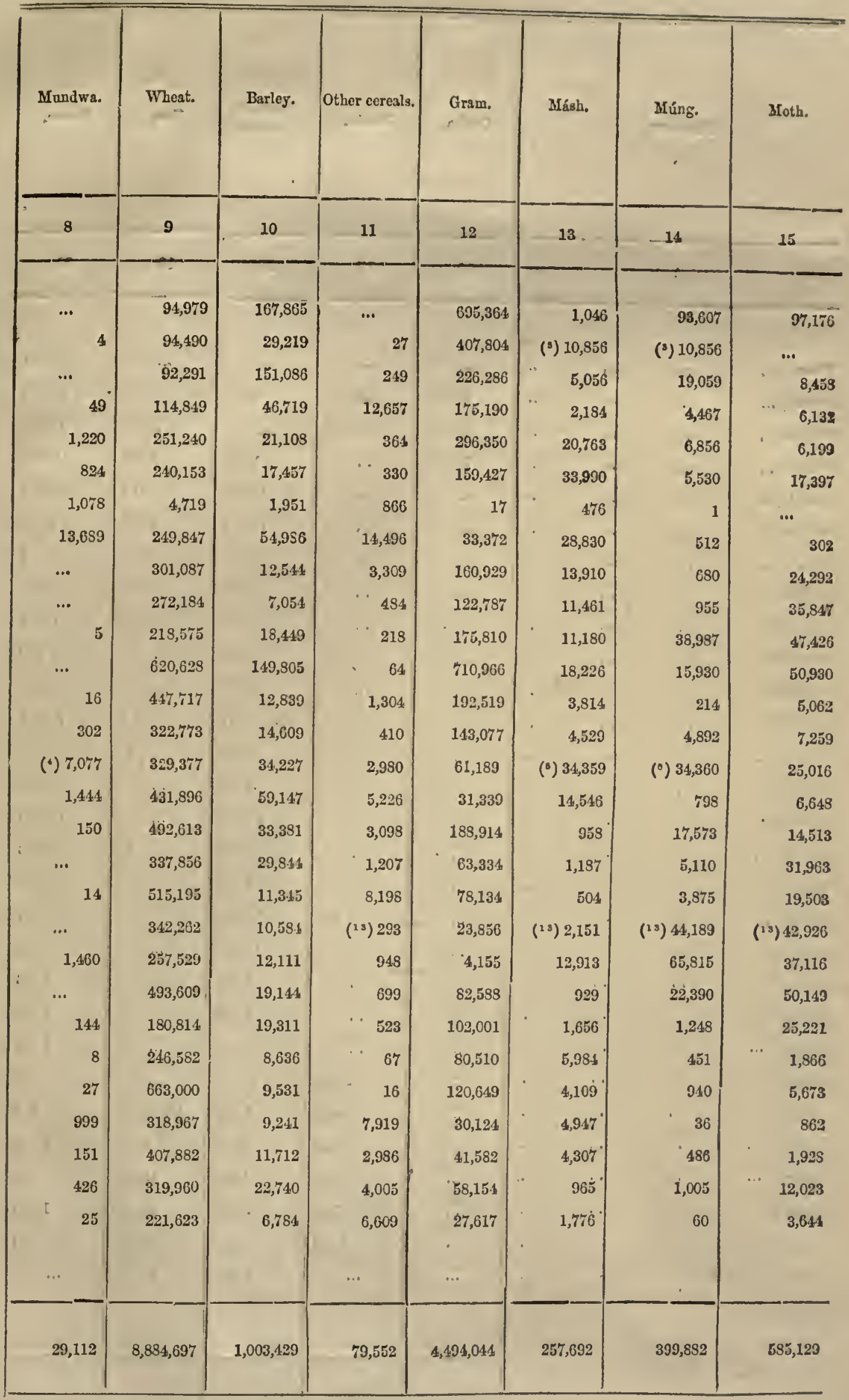

(') Includes sánwat.

(5) In Rohtak 21,712 acres are returuod as míng and másh.

( $\left.{ }^{\circ}\right)$ In Gurdaspur 68,719 acres are returued as ming and másh.

(13) The figures for pulses are taken from distriet revenue registers and exeed those given in Annual Report by about 20,000 acres. 'Ihere is a difference in the contrary direction under "Other cereals.". 
STATEMENT II.-ACRES SOWN IN KIIARIF

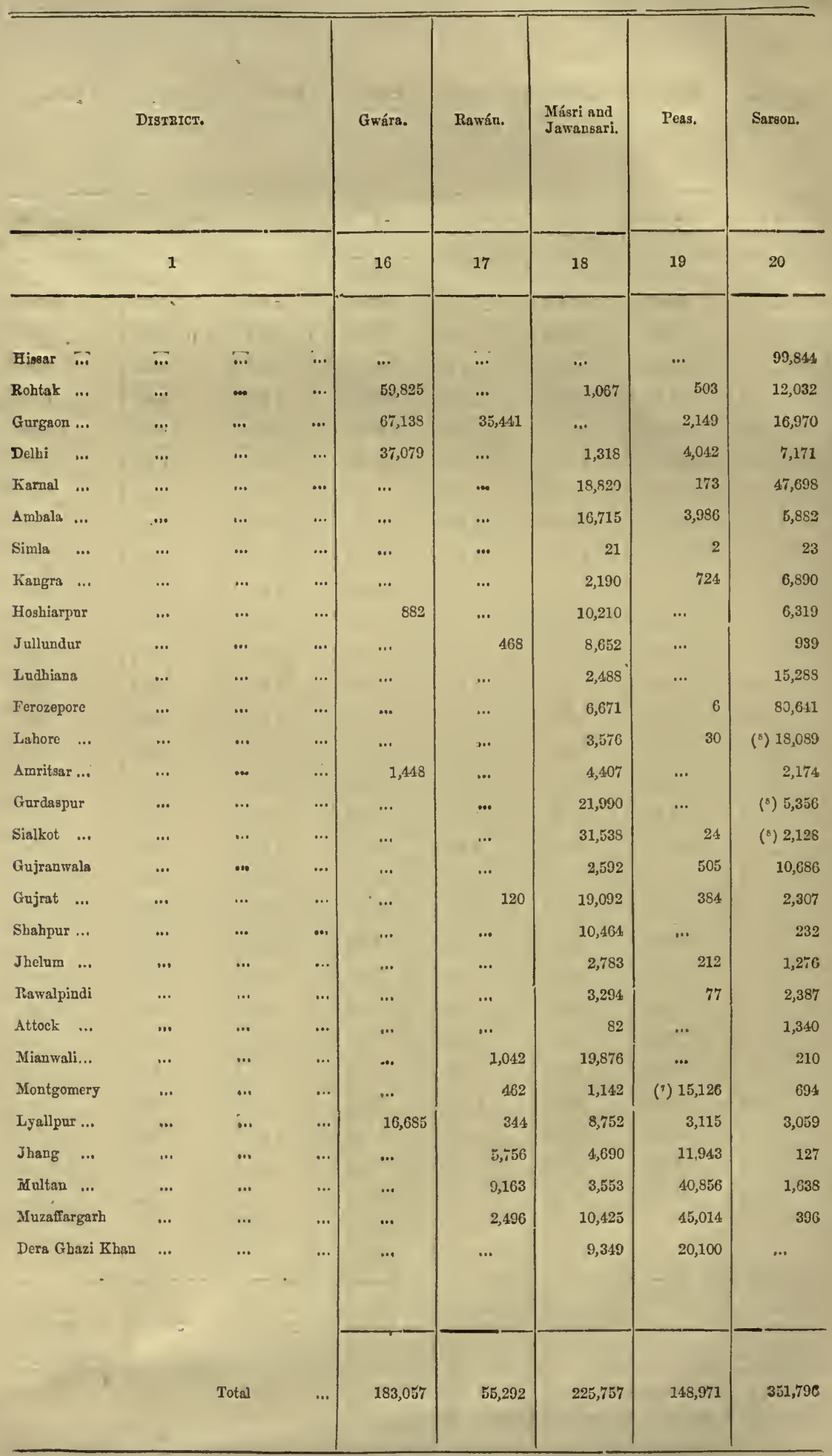


1910-RABI 1911-concluded.

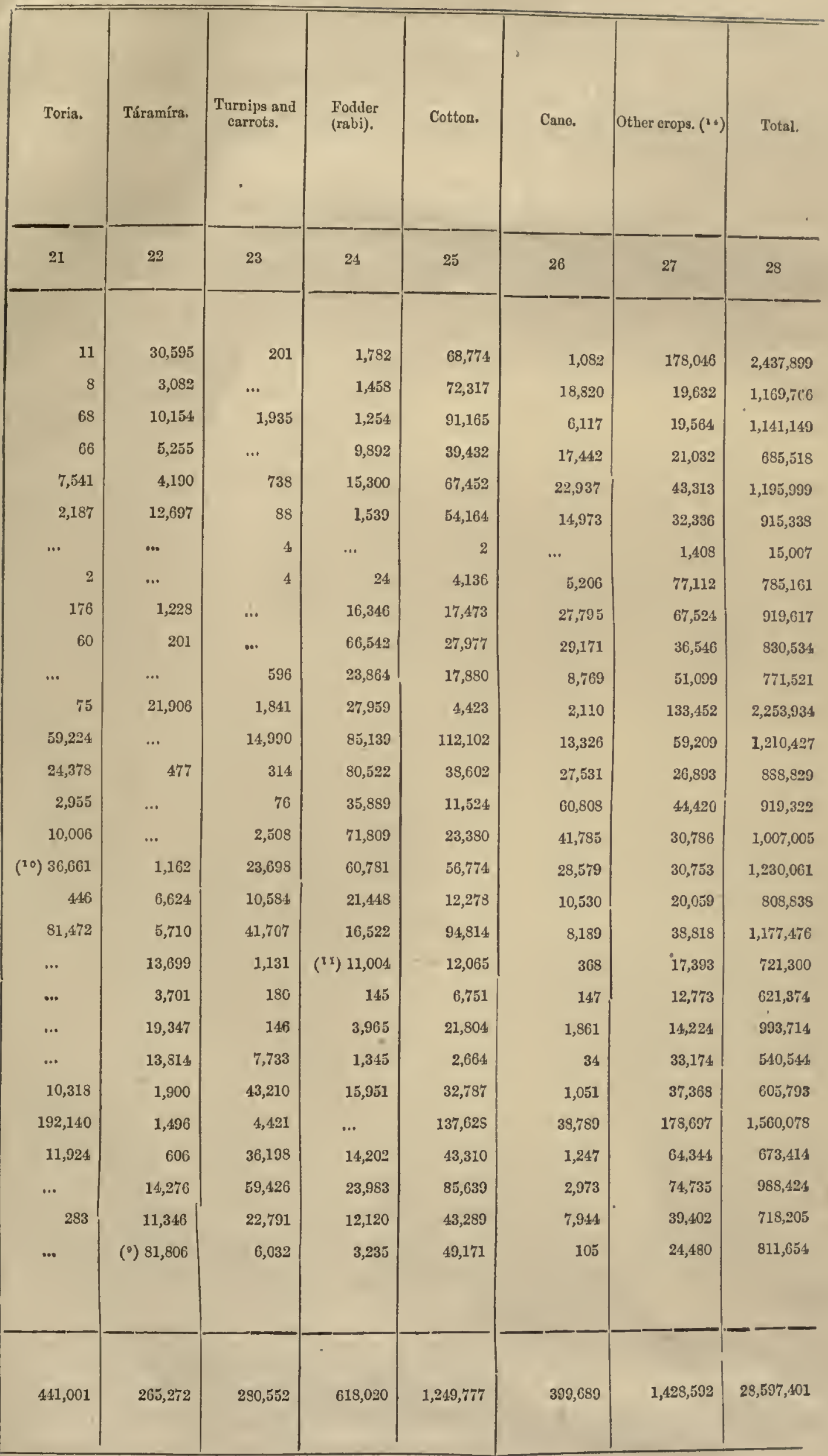

(2) IneIndes sarson and toria.

(20) Fignres from Annual Report of Department of Agricultare.

(11) Includes tornips and carrot.

(14) Differeuce betwcen last column and total of preceding columns. 





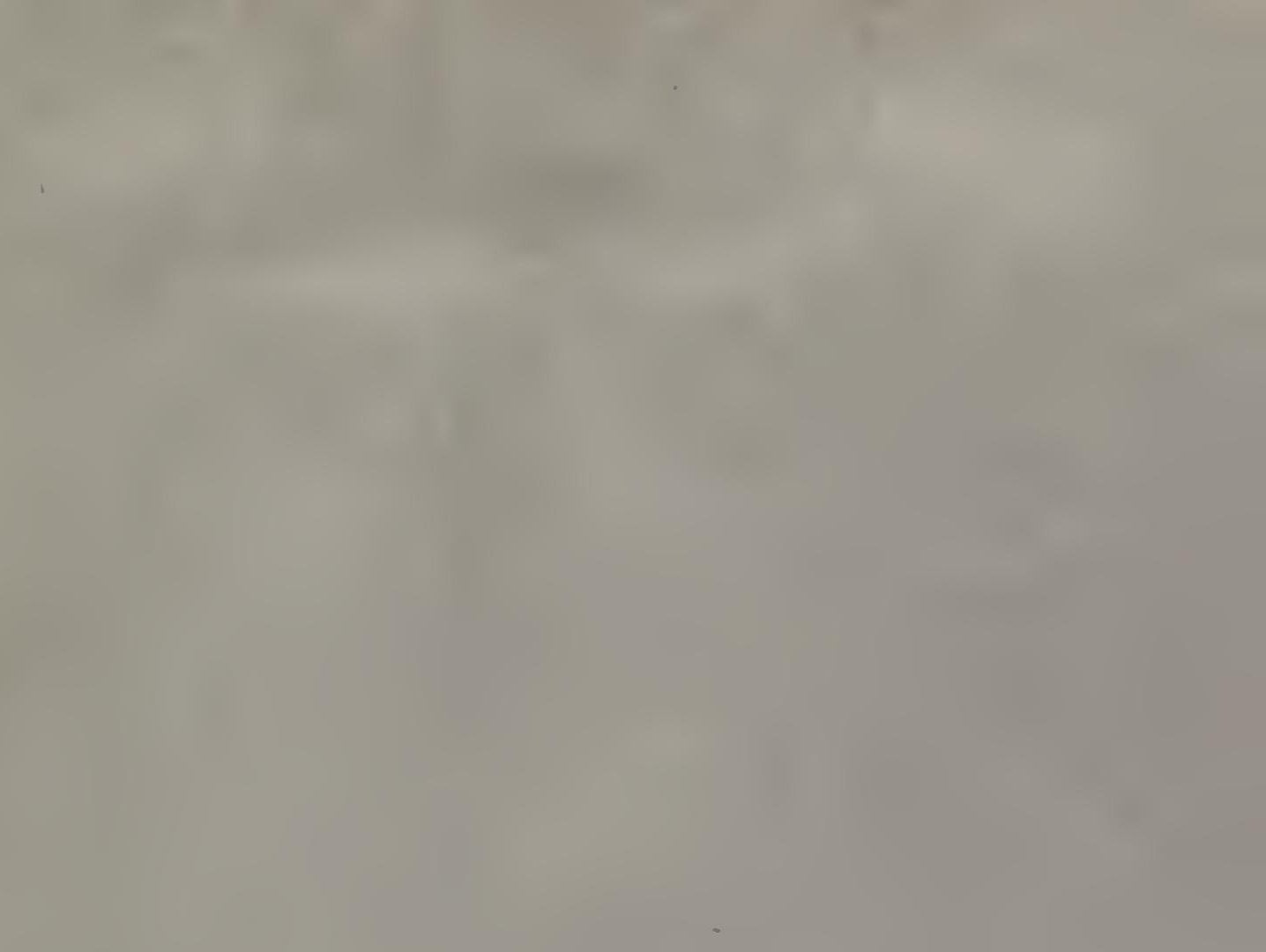


THIS BOOK IS DUE ON THE LAST DATE STAMPED BELOW

RENEWED BOOKS ARE SUBJECT TO IMMEDIATE RECALL

LIBRARY, UNIVERSITY OF CALIFORNIA, DAVIS Bouk Slip-25m-6,'66 (G3855s4) 458 

